JULIANA CORRÊA SANCHEZ DA SILVA

Avaliação do perfil citotóxico da associação de Doxorrubicina com Ivermectina em um modelo celular de melanoma canino

São Paulo

2019 


\title{
Avaliação do perfil citotóxico da associação de Doxorrubicina com Ivermectina em um modelo celular de melanoma canino
}

Dissertação apresentada ao Programa de Pós-Graduação de Patologia Experimental e Comparada da Faculdade de Medicina Veterinária e Zootecnia da Faculdade de Medicina Veterinária e Zootecnia da Universidade de São Paulo para a obtenção do título de Mestre em Ciências.

\section{Departamento:}

Patologia

\author{
Área de concentração: \\ Patologia Experimental e Comparada \\ Orientadora: \\ Profa. Dra. Cristina de Oliveira Massoco \\ Salles Gomes
}

São Paulo 
Autorizo a reprodução parcial ou total desta obra, para fins acadêmicos, desde que citada a fonte.

DADOS INTERNACIONAIS DE CATALOGAÇÃO NA PUBLICAÇÃO

(Biblioteca Virginie Buff D’Ápice da Faculdade de Medicina Veterinária e Zootecnia da Universidade de São Paulo)

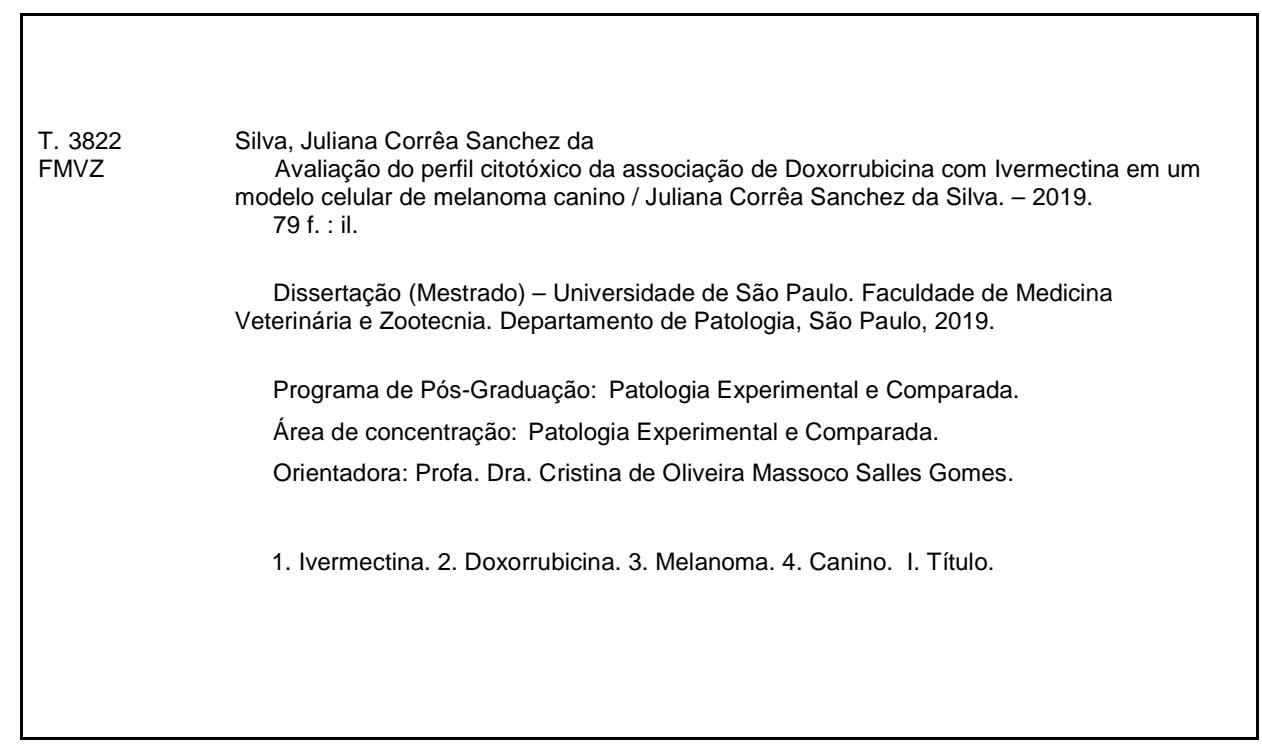

Ficha catalográfica elaborada pela bibliotecária Maria Aparecida Laet, CRB 5673-8, da FMVZ/USP. 
UNIVERSIDADE DE SAOO PAULO

\section{CERTIFIED}

We certify that the Research "Use of ivermectin as a potentiator of the cytotoxic ellect of dowonbicin: an in vitro study on canine melanoma", protocol number CEUAx 5719190218 as wewai, under the responsibility Cristina De Oliveira Massoco 5 alles Gomes. agree with Ethical Principles in Animal Research adopted by Ethic Committee in the Use of Animals of School of Veterinary Medicine and Animal Sclence (University of 5so Paulo), and was apperved in the mecting of day May 09, 2018.

Certificamos que o protocolo do Frojeto de Pesquisa intitulado "Uso da ivemectina como potencializador do efeito citobixico da doworubicina: estudo in vitro em melanoma canino", protocolado sob a CEUAx n\$ 5719190218 , sob a responsabilidade de Cristina De Oiveira Massoco Salles Gomes, estí de acordo com os principios éticos de experimentaçb animal da Comissia de Etica no Uso de Animais da Faculdade de Medicina Veteriniria e Zootecnia da Universidade de Sa Paulo, e foi aprovado na reuni\$o de 09 de mais de 2018 .

$$
\text { (Mrobian Tealon. }
$$

Profa. Dra. Anneliese de Souma Trald:

Presidente da Comissalo de Etica no Uso de Arimais

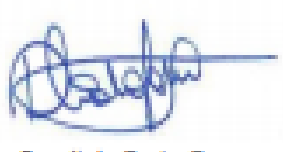

Roseli da Costa Gomes Secretária

Faculdade de Medicina Veterinária e Zootecria da Uniwersidade Faculdade de Medicina Veterinária e Zootecnia da Universidade de Sto Paulo de SSo Pado

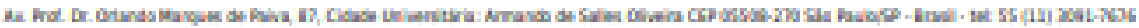

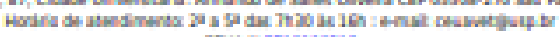


FOLHA DE AVALIAÇÃO

Autor: SILVA, Juliana Corrêa Sanchez

Título: Avaliação do perfil citotóxico da associação de Doxorrubicina com Ivermectina em um modelo celular de melanoma canino

Dissertação apresentada ao Programa de Pós-Graduação de Patologia Experimental e Comparada da Faculdade de Medicina Veterinária e Zootecnia da Universidade de São Paulo para obtenção do título de Mestre em Ciências.

Data:

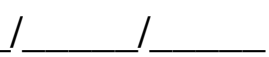

Banca Examinadora

Prof. Dr.

Instituição: Julgamento:

Prof. Dr.

Instituição: Julgamento:

Prof. Dr.

Instituição: Julgamento: 


\section{DEDICATÓRIA}

Dedico essa dissertação:

Aos meu pais Sidney e Cristiane, pelos valores passados e por tudo que sou hoje.

A minha querida avó Maria Dalva que sempre foi meu exemplo de bondade, e pelos momentos mais importantes da minha vida.

Ao meu companheiro Fernando Ponce por sempre me motivar a buscar conhecimento e nunca desistir. 


\section{AGRADECIMENTOS}

Ao final desta jornada, gostaria de agradecer:

Agradeço imensamente a minha orientadora profa. Dra ${ }^{a}$ Cristina de Oliveira Massoco Salles Gomes, pela oportunidade, paciência e confiança para realização deste trabalho e pelos valorosos ensinamentos que carregarei pelo resto de minha vida.

A todos meus amigos do laboratório de Farmacologia e Toxicologia, Nicolle Queiroz- Hazarbassanov, Herculano Pinho Pereira, Vagner Gonçalves Júnior, pela amizade, convivência enriquecedora e por toda troca de conhecimento e experiencias.

Um agradecimento especial a Dra. Nicolle Gilda Teixeira de Queiroz Hazarbassanov por fazer parte dessa trajetória, parte dela como orientadora parte como amiga, agradeço os valiosos ensinamentos, e por fazer parte de diversas etapas de execução do projeto.

Ao Dr. Vagner Gonçalves Júnior pela troca de conhecimento, por auxiliar em diversas etapas do projeto e pela grande amizade que construímos.

Ao prof, Dr. Bruno Cogliati pela generosidade de utilizar seu laboratório e permitir a execução de diversas etapas do projeto.

A Dra. Ivone Izabel Mackowiak da Fonseca que generosamente me ajudou com os protocolos dos ensaios de migração celular.

A toda equipe do laboratório de Imuno-Oncologia Comparada, Jéssica Soares Garcia, Victor Nowosh, Júlia de Carvalho Nakamura e Cássia Corrêa Yasumaru pela amizade, companheirismo, e por deixar tudo mais leve. Obrigada pelas risadas, danças e interpretações no laboratório, sem vocês as disciplinas e dificuldades encontradas durante o mestrado seriam com toda certeza mais difíceis. 
A minha mãe Cristiane Rodriguês Corrêa que sempre esteve presente em todas as situações me apoiando. À mulher que me ensinou o que é ser forte e como se deve encarar as dificuldades da vida. À minha rocha e meu eterno porto seguro, muito obrigada.

Ao meu pai Sidney Sanchez da Silva que sempre foi meu exemplo de pessoa batalhadora, que me ensinou a não desistir e me deu as ferramentas necessárias para seguir o caminho. Obrigada por tudo.

Ao meu grande amigo e irmão Vinicius Corrêa Sanchez da Silva, por me apoiar e estar sempre ao meu lado, por colocar um sorriso no meu rosto mesmo quando parecia impossível.

Ao meu melhor amigo e namorado Fernando Ponce, por estar sempre ao meu lado, enfrentando momentos bons e ruins. Por me deixar chorar quando eu precisava e por saber quando enxugar minhas lagrimas, mas principalmente por torná-las em lagrimas de alegria e gratidão. Por rir comigo e por me acompanhar nos muitos finais de semana escrevendo e realizando experimentos. Por tudo que foi e que ainda temos pela frente, muito obrigada por todo seu amor.

A todos meus familiares, pelo apoio e exemplos, em especial as minhas tias Eliane Rodriguês Corrêa, Solange Rodriguês Corrêa e meu tio Oswaldo Tadeu Rodriguês Corrêa e meu primo que considero um irmão Douglas Barbosa Corrêa.

Ao meu amigo e Professor André Rinaldi Fukushima por me mostrar esse valioso caminho da ciência e fazer despertar o interesse e mostrar como podemos fazer a diferença para muitas pessoas.

A Adriana pelo carinho e a grande amizade que construímos, e pela ótima companhia durante os almoços.

A Verônica Pitorri por ter me ajudado durante várias etapas do projeto e sempre ser tão solicita quando precisei.

As minhas amigas de laboratório Andrea Midory Miyake e Tatícia Ikeda por compartilharem seus conhecimentos e pelas boas conversas nos corredores.

Os meus grandes amigos que sempre me acompanharam, André, Andressa, Bruna, Caroline, Diego, Evandro, Fernanda, Pedro, Rafael, 
agradeço cada um por fazer parte da minha trajetória, e por tornar cada momento inesquecível. E uma coisa eu sempre digo das amizades que formei durante os anos, as pessoas entram na nossa vida por um acaso, mas não é por um simples acaso que elas permanecem.

Ao Conselho Nacional de Desenvolvimento Científico e Tecnológico (CNPq) pelo apoio financeiro e no desenvolvimento desse trabalho.

A todos os animais que contribuíram e participaram deste estudo.

E um último agradecimento mais que especial para minha vozinha Maria Dalva Gardim, de quem eu ainda sinto muita falta, e que sempre foi e será a minha estrela guia. 
"A tragédia do homem é o que morre dentro dele enquanto ele ainda está vivo." 


\section{RESUMO}

SILVA, J., C., S. Avaliação do perfil citotóxico da associação de Doxorrubicina com Ivermectina em um modelo celular de melanoma canino. 2019. Dissertação (Mestrado em Ciências) - Faculdade de Medicina Veterinária e Zootecnia, Universidade de São Paulo, São Paulo, 2019.

A Ivermectina (IV) é uma lactona macrocíclica comumente utilizada no tratamento de parasitoses humanas e como endectocida na medicina veterinária, porém evidências tanto em modelos in vitro como in vivo indicam que a ivermectina pode exercer efeitos antitumorais de maneira isolada ou sinérgica. Assim, o presente estudo teve como objetivo investigar os efeitos da associação de Doxorrubicina com a Ivermectina em um modelo celular in vitro de melanoma canino para verificar um efeito sinérgico entre esses fármacos. Para tanto, foi realizada a avaliação da citotoxidade, via de morte celular, alterações sobre o ciclo celular e ensaio de migração das células tumorais após 48 horas de tratamento. No presente estudo foi

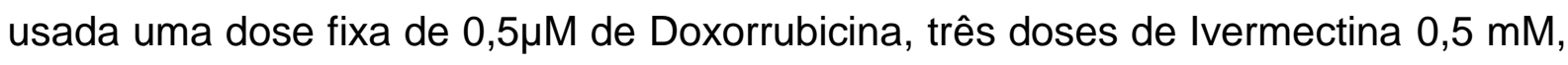
$1,5 \mathrm{mM}$ e 2,5 mM, e as respectivas associações em combinação com as diferentes doses de Ivermectina, além de um controle apenas com as células tumorais sem tratamento e o DMSO (veículo). Os resultados demonstram que a associação

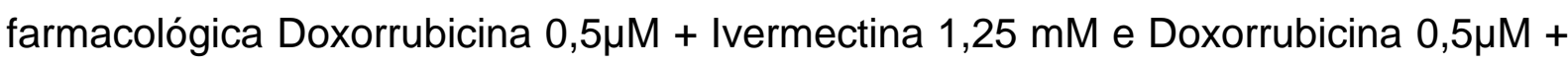
Ivermectina 2,5 mM aumentou significativamente o percentual de citotoxicidade celular pela via de necrose em relação aos controles e às drogas isoladas. No ensaio de avaliação do ciclo celular a ivermectina aumentou o bloqueio em G2/M induzido pela Doxorrubinina. O método de migração celular (wound healing), revelou que a associação foi capaz de diminuir a migração das células tumorais, sendo mais eficaz que a Doxorrubicina $0,5 \mu \mathrm{M}$ isolada. É possível que esse mecanismo sinérgico da Ivermectina possa ter relação com a reversão da resistência por interagir com a glicoproteína-P ou mesmos outros componentes ligados as proteínas expressas pelo fator (MDR). Conclui-se que a associação de Doxorrubicina e Ivermectina foi mais citotóxica que o tratamento de Doxorrubicina isolada, norteando novas pesquisas no ramo de reposicionamento farmacológico ou até mesmo em uma nova abordagem terapêutica.

Palavras chave: Ivermectina. Doxorrubicina. Melanoma. Canino. 
ABSTRACT

SILVA, J., C., S. Evaluation of the cytotoxic profile of the association of Doxorubicin with Ivermectin in a canine melanoma cell model. 2019. Dissertação (Mestrado em Ciências) - Faculdade de Medicina Veterinária e Zootecnia, Universidade de São Paulo, São Paulo, 2019

Ivermectin (IV) is a macrocyclic lactone commonly used in the treatment of human parasites and as endectocidal in veterinary medicine, but evidence in both in vitro and in vivo models indicates that ivermectin may exert antitumor effects in isolation or synergistically. Thus, the present study aimed to investigate the effects of the association of Doxorubicin with Ivermectin in an in vitro canine melanoma cell model to verify a synergistic effect between these drugs. Therefore, we evaluated cytotoxicity, cell death pathway, cell cycle changes and tumor cell migration assay after 48 hours of treatment. In the present study, a fixed dose of $0.5 \mu \mathrm{M}$ Doxorubicin, three doses of $0.5 \mathrm{mM}, 1.5 \mathrm{mM}$ and $2.5 \mathrm{mM}$ Ivermectin, and their combinations in with the different doses of Ivermectin, were used the control only with untreated tumor cells and DMSO (vehicle). The results demonstrate that the pharmacological association Doxorubicin $0.5 \mu \mathrm{M}+$ Ivermectin $1.25 \mathrm{mM}$ and Doxorubicin $0.5 \mu \mathrm{M}+$ Ivermectin $2.5 \mathrm{mM}$ significantly increased the percentage of necrosis cell cytotoxicity in relation to controls and drugs alone. In the cell cycle evaluation assay ivermectin increased Doxorubinin-induced G2/M blockade. The wound healing method revealed that the association was able to decrease tumor cell migration, being more effective than Doxorubicin $0.5 \mu \mathrm{M}$ alone. It is possible that this synergistic mechanism of Ivermectin may be related to the reversal of resistance by interacting with $\mathrm{P}$ glycoprotein or even other protein-bound components (MDR). It was concluded that the combination of Doxorubicin and Ivermectin was more cytotoxic than Doxorubicin treatment alone, guiding further research in the field of pharmacological repositioning or even in a new therapeutic approach.

Key words: Ivermectin. Doxorubicin. Melanoma. Canine. 



\section{LISTA DE FIGURAS}

Figura 1 - Métodos e ferramentas que exploram drogas, doenças e redes de dados biomoleculares, que convergem na identificação de oportunidades de reaproveitamento de drogas

Figura 2 - Estrutura molecular da Avermectina, e as formas estruturais de seus 8 compostos derivados, esses complexos apresentavam redução da dupla ligação nos carbonos C22 e C23 nos quais atribuíram uma melhor capacidade tanto no espectro de atividade da molécula como o aspecto de segurança, resultando em uma diminuição da toxicidade em mamíferos.....

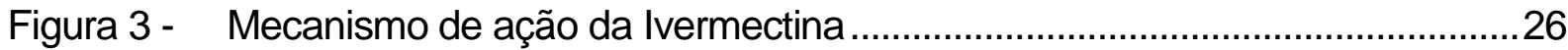

Figura 4 - Molécula da Doxorrubicina....................................................................30

Figura 5 - Mecanismo de funcionamento da glicoproteína-P (Gp-P), mostrando a função normal da Gp-p na membrana plasmática de uma célula cancerígena durante o efluxo de um fármaco. A ativação da bomba de efluxo pela hidrólise de uma molécula de ATP ligada conduz as moléculas do fármaco citotóxico para fora da célula ..................................34

Figura 6 - Ilustração da técnica de Wound Healing ...................................................4 44

Figura 7 - Fotomicrografia da linhagem tumoral em cultivo .....................................46

Figura 8 - Imagem de fragmentos de agarose a $2 \%$, nos quais as células tumorais foram incluídas, em cassete histológico para inclusão em parafina e microtomia

Figura 9 - Fotomicrografia de corte histológico de células de melanoma oral canino (MeLn) incluídas em agarose $2 \%$ (cell block)

Figura 10 - Fotomicrografia representativa da reação imunohistoquímica para Melan A (seta) de células incluídas pela técnica de cell block provenientes do cultivo celular da linhagem MeLn

Figura 11 - Fotomicrografia representativa da reação imunoistoquímica para PNL-2

Figura 12 - Efeitos da associação de diferentes concentrações da Doxorrubicina e Ivermectina no ciclo celular de uma linhagem de melanoma metastático canino (Meln)

Figura 13 - Curva de crescimento celular na concentração de $0,5 \times 106 / \mathrm{ml}$ de acordo com o tempo

Figura 14 - Curva de crescimento celular na concentração de $1,5 \times 106 / \mathrm{ml}$ de acordo com o tempo

Figura 15 - Fotomicrografias das células na concentração de $0,5 \times 10^{6}$ nos tempos de 0 a 96 horas

Figura 16 - Fotomicrografias das células na concentração de $1,5 \times 10^{6}$ nos tempos de 0 a 96 horas 
Figura 17 - Valores referentes a média \pm desvio da porcentagem da viabilidade das células no arranjo esferoides de uma linhagem de melanoma metastático canino expostas às diferentes concentrações de ivermectina e doxorrubicina e suas associações, assim como o respectivo controle e (DMSO) em cada placa de 24 poços

Figura 18 - Efeito dos diferentes tipos de tratamento na migração células tumorais de melanoma canino metastático, avaliados nos tempos Ohrs, $24 \mathrm{hrs}$ e $48 \mathrm{hrs}$. O ensaio foi feito em triplicata e as imagens correspondem a umas das triplicatas

Figura 19 - Efeito dos diferentes tipos de tratamentos na migração das células tumorais de melanoma canino metastático. $\mathrm{O}$ ensaio foi realizado em triplicata

Figura 20 - Efeito dos diferentes tipos de tratamentos na migração das células tumorais de melanoma canino metastático. $O$ ensaio foi realizado em triplicata.

Figura 21 - Gráfico representativo da análise de ciclo celular pós tratamentos avaliado pela técnica de citometria de fluxo 


\section{LISTA DE TABELAS}

Tabela 1 - Resumo de alvos antitumorais da ivermectina ...........................................29

Tabela 2 - Valores referentes a média \pm desvio padrão da porcentagem de células em apoptose inicial, apoptose tardia e necrose após 48 horas.......................54 
SUMÁRIO

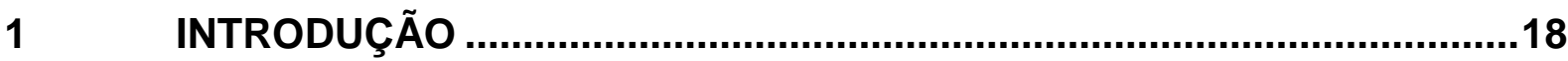

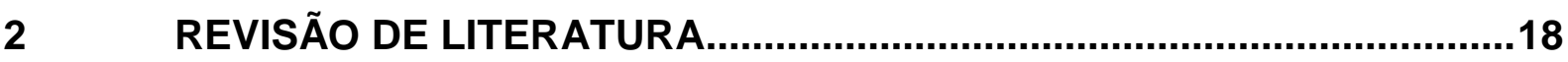

2.1 REPOSICIONAMENTO FARMACOLÓGICO …........................................ 18

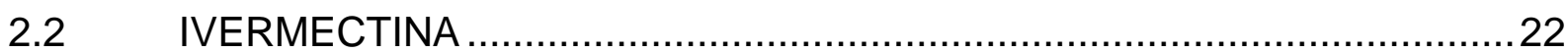

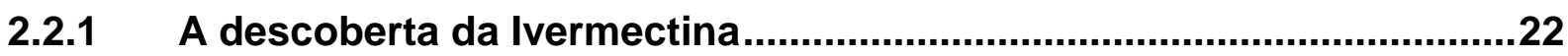

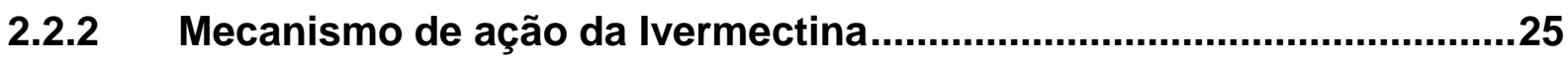

2.2.3 Mecanismo antitumorais da Ivermectina...........................................27

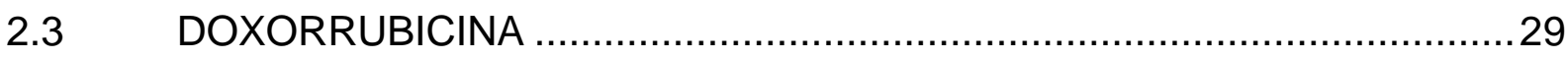

2.3.1 Mecanismo de ação da Doxorrubicina ..................................................31

2.4 MECANISMO DE RESISTÊNCIA A MÚLTIPLAS DROGAS MEDIADA PELA GLICOPROTEÍNA-P NO CENÁRIO DA ONCOLOGIA .....................32

2.5 MELANOMA

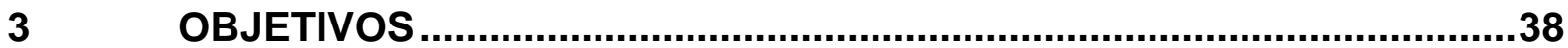

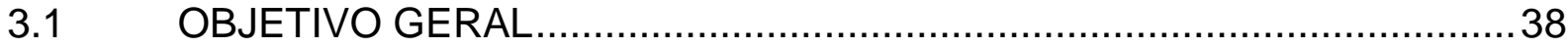

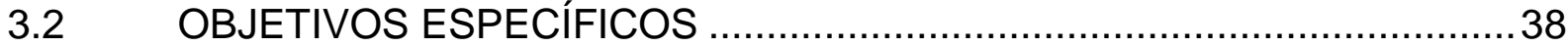

$4 \quad$ MATERIAIS E MÉTODOS

4.1 OBTENÇÃO E CARACTERIZAÇÃO DA LINHAGEM DE MELANOMA

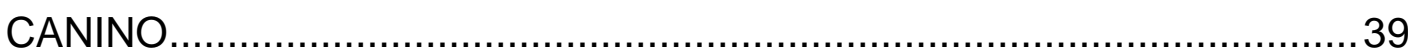

4.1.1 Obtenção da linhagem de melanoma ….............................................39

4.1.2 Imuno-histoquimica (Mela-A e PNL-2) ….............................................39

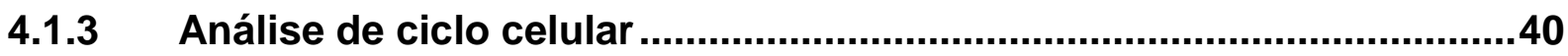

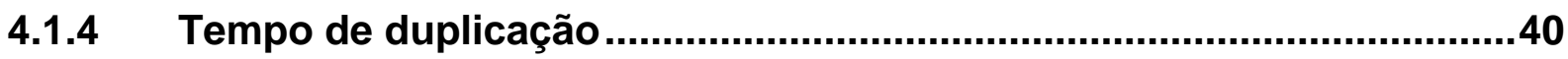

4.2 TRATAMENTO COM AS ASSOCIAÇÕES FARMACOLÓGICAS...............41

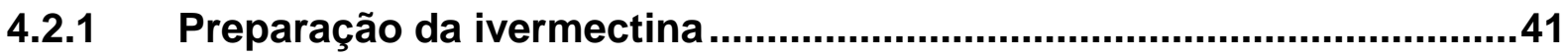

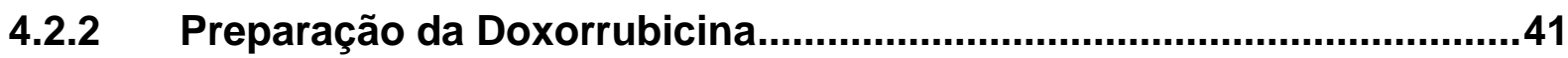


4.2.3 Cultivo tridimensional de melanoma canino.......................................41

4.2.4 Tratamento células tumorais (MeLn) ……........................................... 42

4.2.5 Análise do Mecanismo de Morte Celular: ensaio de apoptose e necrose (Anexina V-FITC/lodeto de Propídeo)......................................42

4.2.6 Ensaio de Migração celular- Método de Wound Healing .......................43

4.2.7 Análise do ciclo celular pós tratamento ................................................45

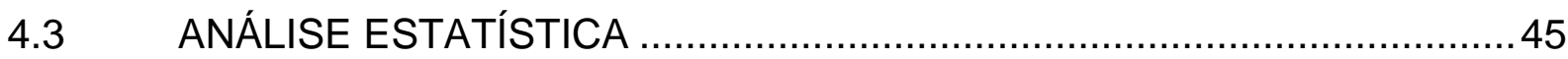

$5 \quad$ RESULTADOS

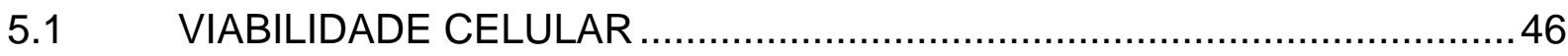

5.2 ANÁLISE MORFOLÓGICA DA LINHAGEM TUMORAL CANINA ..............46

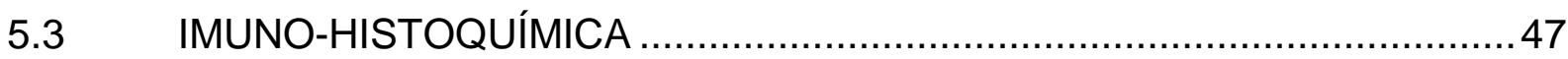

5.4 CICLO CELULAR DA LINHAGEM DE MELANOMA (MELN) ..................49

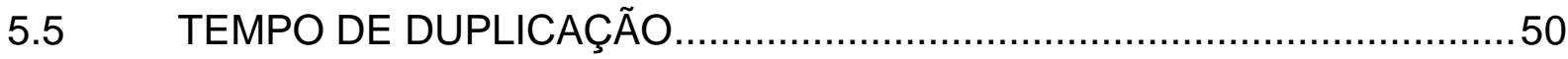

5.6 AVALIAÇÃO DA CITOTOXICIDADE PÓS TRATAMENTO ........................52

5.7 AVALIAÇÃO DO PERFIL APOPTÓTICO E NECRÓTICO PÓS

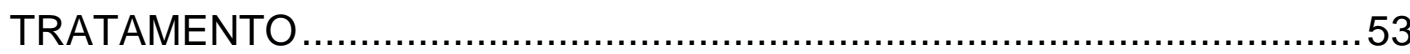

5.8 AVALIAÇÃO DA MIGRAÇÃO CELULAR- MÉTODO WOUND HEALING...55

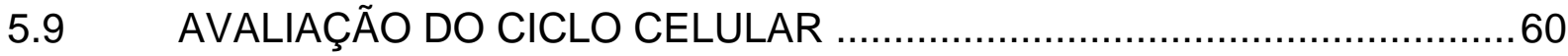

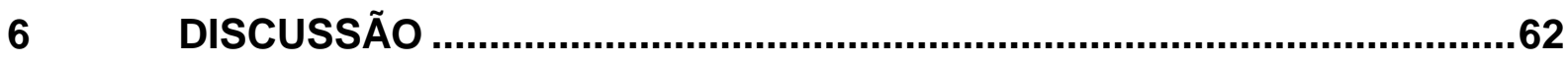

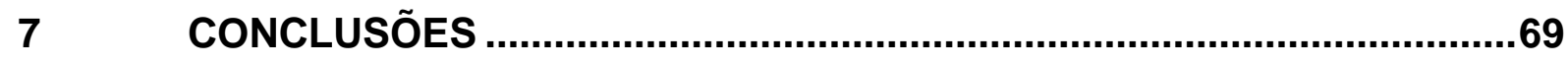

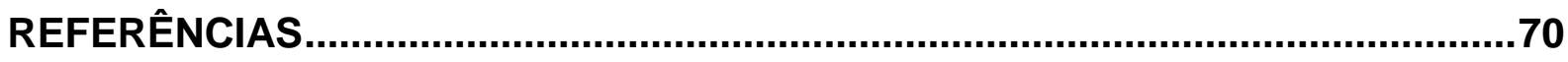




\section{INTRODUÇÃO}

No cenário da medicina atual, onde cada vez mais o número de novos medicamentos e classes terapêuticas desenvolvidas por indústrias farmacêuticas está diminuindo gradualmente, mesmo com investimentos consistentes na área de pesquisa desenvolvimento e inovação tornou-se necessário buscar alternativas para suprir essa carência farmacológica, principalmente no ramo da oncologia veterinária (WÜRTH et al., 2016)

Neste sentido, o reposicionamento de fármacos é uma forma de inovação no ramo da indústria farmacêutica e representa uma maneira inteligente de explorar novos alvos moleculares de uma droga previamente conhecida para o tratamento de diferentes doenças com o uso do fármaco com indicação diferenciada do original (WÜRTH et al., 2016).

Tanto na medicina humana como na veterinária, o insucesso do tratamento de tumores, em parte é atribuída à expressão de transportadores transmembrânicos, conhecidos também como bomba de efluxo. Estudos já elucidaram algumas dessas proteínas responsáveis pelo mecanismo de resistência a drogas conhecida pela sigla (MDR), sendo a expressão da glicoproteína-P (Gp-P) uma das principais causas desse insucesso terapêutico. A glicoproteína-P presente na membrana celular, atua como uma bomba de efluxo de alguns xenobióticos, mas em tumores sua expressão é elevada, sendo correlacionada com baixa resposta clínica à quimioterapia e diminuição da sobrevida dos pacientes (POULIOT et al., 1997).

Certas drogas lipofílicas se ligam à Gp-P e invertem o fenótipo MDR das células tumorais. Foi verificada evidências da capacidade da ivermectina (IVM), um fármaco antiparasitário, ser reversor de MDR, cujos resultados mostraram que a IVM interage diretamente com o sítio de ligação da Gp-P, saturando o mesmo e permitindo que outros fármacos adentrem na célula sem que esse sistema seja capaz de eliminá-los (POULIOT et al., 1997).

Já foi demonstrado, em uma linhagem tumoral murina que a presença da ivermectina é capaz de induzir um aumento da sensibilidade das células à doxorrubicina, ocasionado pela mudança potencial de membrana plasmática nas células resistentes à doxorrubicina, auxiliando a mesma a adentrar nas células e, consequentemente, gerar um aumento de morte celular (FURUSAWA et al., 2000). 
Sabe-se que este quimioterápico sofre translocação nuclear pela Gp-P resultando na quimiorresistência das células tumorais (BAO et al., 2012).

Tendo em vista o desafio atual para o controle e remissão de algumas neoplasias, em especial o melanoma, o presente estudo tem como objetivo avaliar o efeito da associação farmacológica entre a doxorrubicina e a ivermectina considerando um novo escopo para o reposicionamento farmacológico desta última em um modelo in vitro de melanoma canino. 


\section{REVISÃO DE LITERATURA}

\subsection{REPOSICIONAMENTO FARMACOLÓGICO}

O reposicionamento farmacológico baseia-se no reaproveitamento de drogas e a identificação de novas indicações terapêuticas para medicamentos já aprovados. O reposicionamento vem despertando cada vez mais o interesse das indústrias, permitindo o reaproveitamento dos medicamentos, para os quais estudos préclínicos envolvendo segurança, foram previamente realizadas, ou seja, permite uma tradução mais rápida, mais barata e mais eficiente encurtando ainda mais o caminho para o registro do medicamento com a nova indicação de uso (LANGEDIJK et al., 2015; WÜRTH et al., 2016).

Atuais avanços no ramo da biotecnologia concedem uma rápida descoberta de medicamentos e seu potencial reposicionamento para doenças muitas vezes de difícil tratamento como o câncer, desordens do sistema nervoso central e doenças raras, ampliando ainda mais o portifólio de indicações dos medicamentos e tornando uma nova abordagem estratégica (WÜRTH et al., 2016).

Diversas ferramentas são empregadas para descoberta de novos alvos moleculares, como modelos computacionais conhecido como in silico, modelagem genômica e o modo usual, que implica na utilização de bases de dados através de pesquisas ativas em indexadores, e a descoberta de artigos referentes a novos efeitos relatados com o uso do fármaco, reações adversas e até mecanismos antes não estudados (Figura 1) (SHAMEER; READHEAD; DUDLEY, 2015).

Além disso, as abordagens computacionais e os bancos de dados são capazes de identificar possíveis sinergismos entre combinações de drogas existentes, através do rastreamento de redes moleculares e a combinação com receptores celulares e outros possíveis ligantes (SHAMEER; READHEAD; DUDLEY, 2015). 
Figura 1 - Métodos e ferramentas que exploram drogas, doenças e redes de dados biomoleculares, que convergem na identificação de oportunidades de reaproveitamento de drogas

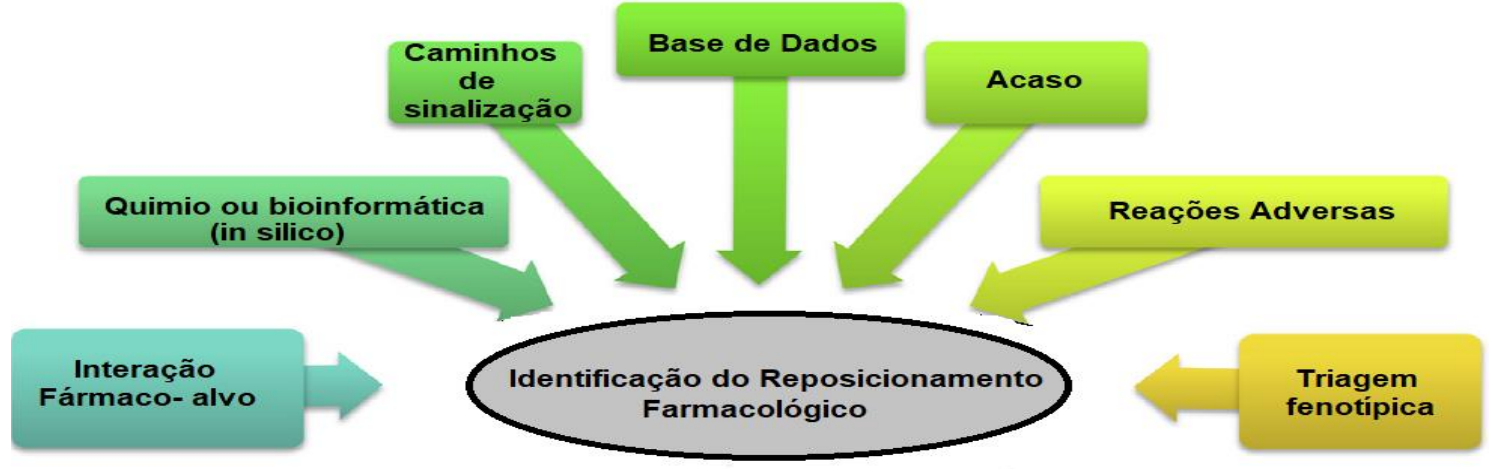

Fonte: Figura adaptada WURTH, et al., 2016.

Mesmo com a utilização dessa tecnologia, diversas entidades não ficam isentas de realizar uma validação em modelos experimentais in vitro e in vivo, ou por registros eletrônicos de saúde. Levando em conta que apesar de uma ótima alternativa, o reposicionamento farmacológico não é completamente isento de riscos, representando uma fase de desenvolvimento de medicamentos, testes referentes a sua atividade biológica, verificação de parâmetros farmacológicos e clínicos, além da necessidade de averiguar possíveis insucessos em ensaios clínicos tardios ou após a comercialização (LANGEDIJK et al., 2015).

O processo envolvido para nova indicação do medicamento, implica em:

(I) novos grupos de paciente com a condição fisiopatológicas referente a nova indicação;

(II) novas formulações de medicamentos com biodisponibilidade e farmacocinética diversificadas;

(III) nova dosagem, especialmente se usado em concentrações terapêuticas diferente do registro original e toxicidades imprevistas.

Todas essas precauções e abordagens são necessárias para atender aos rigorosos requisitos de segurança antes de dar início ao registro desse fármaco com nova indicação terapêutica (WÜRTH et al., 2016).

Alguns tipos de neoplasias desenvolvem resistência a drogas através de proteínas de efluxo, ou seja, jogando o quimioterápico para fora das células; dessa 
forma uma única via ou componente não é suficiente para prejudicar o crescimento do tumor, enquanto que a utilização de múltiplos alvos, usando drogas combinadas pode melhorar a eficácia das terapias antineoplásicas (VAN DEN OORD et al., 2013).

Com a grande dificuldade da aprovação de novos compostos e de fracassos correlacionados aos ensaios de fase I de agentes antineoplásicos, além do elevado custo para produzir essa classe de medicamentos, torna-se necessário consolidar o reaproveitamento de medicamentos, sendo uma abordagem promissora para 0 tratamento na oncologia (GUPTA et al., 2013; HAY et al., 2014).

\subsection{IVERMECTINA}

\subsubsection{A descoberta da Ivermectina}

A ivermectina (IVM) é uma lactona macrocíclica, derivado das avermectinas B1, comumente utilizada para o tratamento de infecções parasitárias, a mesma é empregada na medicina humana desde 1987. A IVM também tem sido usada na medicina veterinário para tratamento de diversos parasitas, vermes gastrointestinais, vermes pulmonares e ácaros (ÕMURA, 2008).

Inicialmente a descoberta das lactonas macrocíclicas se deu em meados da década de 1970 pelo microbiologista Satoshi Omura no Instituto Kitasato em Tóquio no Japão, em parceria com a indústria farmacêutica Merck, Sharpe e Dohme (MSD), onde a empresa buscava novas substâncias com potencial terapêutico para uso veterinário (ÕMURA, 2008).

A ivermectina é um membro semi-sintético de uma classe de compostos chamados avermectinas, que foram isolados do caldo da fermentação da bactéria Streptomyces avermectinius, uma espécie de actinomiceto encontrada no solo perto de um campo de golfe margeando o oceano no Japão (ÕMURA, 2008)

Em 1974 a cultura isolada por Omura foi enviada para os laboratórios da MSD, juntamente com 53 outras amostras microbianas para realizar os testes e identificações de possíveis substâncias com efeitos promissores. As amostras foram testadas em um modelo de rato de infecção por helmintos, onde os ratos foram 
infectados com o verme nematoide Nematospiroides dubius. Após os experimentos, verificaram que a amostra microbiana originalmente identificado como OS-3153, cepa $S$. avermectinius demonstrou ter atividade anti-helmíntica potente e com baixa ou até mesmo nenhuma toxicidade. Dessa forma o composto responsável pela atividade foi denominado avermectina, onde é compreendida como um complexo de 16 membros das lactonas macrocíclicas e a fermentação de $S$. avermectinius dá origem a oito compostos de avermectinas (A1a, A1b, A2a, A2b, B1a, B1b, B2a e B2b) (FIG. 2) (BURG et al., 1979; ÕMURA, 2008;).

Os membros da família das avermectinas incluem, selamectina, abamectina, monoxidectina e ivermectina, todos os quais diferem das lactonas macrocíclicas antibacterianas e antifúngicas de 16 membros (BURG et al., 1979).

As avermectinas originaram uma nova classe denominada 'endectocidas' devido sua capacidade única de matar ecto- e endoparasitas, onde diversos estudos demonstraram a sua atividade biocida contra uma diversos nematódeos, aracnídeos e insetos. Além disso, o mecanismo de ação das avermectinas foi considerado único e 25 vezes mais potente que todos os anti-helmínticos disponíveis no mercado na época (BURG et al., 1979; EGERTON et al., 1979 ).

Com esse conhecimento consolidado sobre a estrutura da molécula e seus efeitos sistêmicos menos tóxicos, a MSD iniciou o processo de síntese desse novo composto a partir da avermectina e o complexo 22,23-dihidroavermectina-B1a e dihidroavermectina-B1b, resultante de uma mistura de $80 \%$ B1a e 20\% B1b, onde foi nomeado genericamente de Ivermectina e comercializado no ano de 1981(BURG et al., 1979; EGERTON et al., 1979). 
Figura 2 - Estrutura molecular da Avermectina, e as formas estruturais de seus 8 compostos derivados, esses complexos apresentavam redução da dupla ligação nos carbonos C22 e C23 nos quais atribuíram uma melhor capacidade tanto no espectro de atividade da molécula como o aspecto de segurança, resultando em uma diminuição da toxicidade em mamíferos.

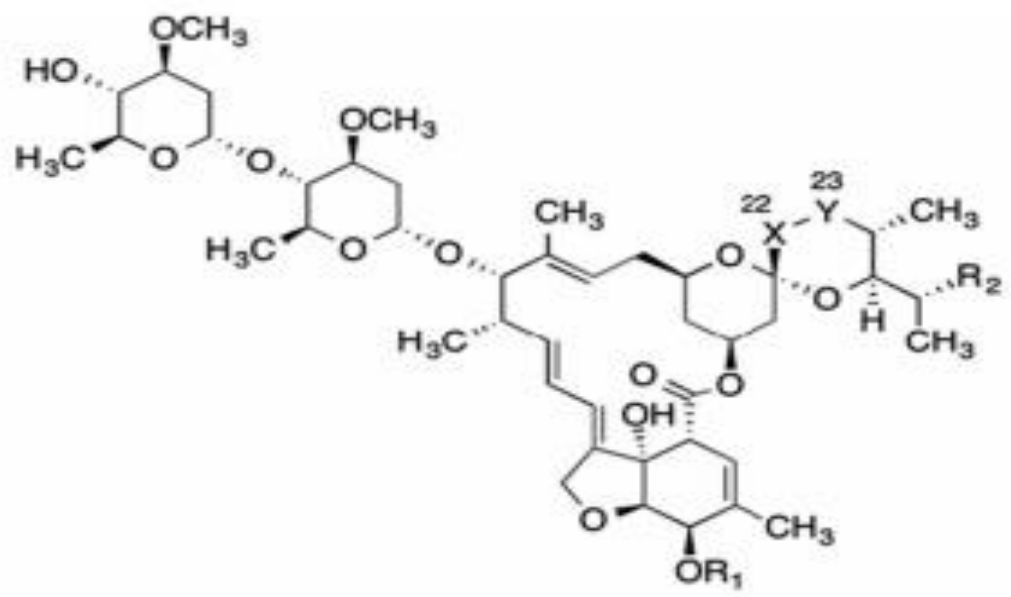

Avermectin $\mathrm{A}_{1 \mathrm{a}}\left[\mathrm{R}_{1}=\mathrm{CH}_{3} ; \mathrm{R}_{2}=\mathrm{C}_{2} \mathrm{H}_{5} ; \mathrm{X}-\mathrm{Y} \rightleftharpoons \mathrm{m}=\mathrm{J}\right.$

$\mathrm{A}_{1 \mathrm{~b}}\left[\mathrm{R}_{1}=\mathrm{R}_{2}=\mathrm{CH}_{3} ; \mathrm{X}-\mathrm{Y}=\mathrm{r}_{1}-\mathrm{T}\right]$

$A_{2 a}\left[R_{1}=\mathrm{CH}_{3} ; \mathrm{R}_{2}=\mathrm{C}_{2} \mathrm{H}_{5}: \mathrm{X}-\mathrm{Y}=\mathrm{CH}_{2}-\mathrm{CH}(\alpha-\mathrm{OH})\right]$

$A_{2 b}\left[R_{1}=R_{2}=C_{3} ; X-Y=C_{2}-C H(\alpha-O H)\right]$

$B_{1 a}\left[R_{1}=H ; R_{2}=C_{2} H_{5} ; X-Y \Rightarrow-3\right]$

$B_{1 b}\left[R_{1}=H_{;} ; R_{2}=C_{3} ; X-Y=2-3\right]$

$B_{2 a}\left[R_{1}=H ; R_{2}=C_{2} H_{5} ; X-Y=C_{2}-C H(\alpha-O H)\right]$

$B_{2 b}\left[R_{1}=\mathrm{H} ; R_{2}=\mathrm{CH}_{3} ; X-Y=\mathrm{CH}_{2} \cdot \mathrm{CH}(\alpha-\mathrm{OH})\right]$

Ivermectin: mixture of dihydroderivatives of

$B_{1} \quad\left[R_{1}=\mathrm{H} ; R_{2}=C_{2} H_{5} ; X-Y=C_{2}-C_{2}\right]$

$\mathrm{B}_{1 \mathrm{~b}}\left[\mathrm{R}_{1}=\mathrm{H} ; \mathrm{R}_{2}=\mathrm{CH}_{3} ; \mathrm{X}-\mathrm{Y}=\mathrm{CH}_{2}-\mathrm{CH}_{2}\right]$

Fonte:(ÕMURA; CRUMP, 2004)

Análises posteriores revelaram que a ivermectina foi altamente eficaz contra ácaros, carrapatos, assim como uma atividade notável contra endo- bem como ectoparasitas em cavalos, gado, porcos e ovelhas. Ivermectina também foi encontrado para ser bem-sucedido na eliminação de vermes no estado larval, mas não vermes adultos, e poderia ser usado para tratar sarna e outras condições em cães (ÕMURA; CRUMP, 2004).

Mais tarde outros membros das lactonas macrocíclicas, abamectina, doramectina, epinomectina e selamectinas tiveram seus efeitos elucidados com maior aprofundamento científico e relevaram propriedades ecto-endoparasitárias (GEARY, 2005).

No ano de 1999, o grupo do no Instituto Kitasato identificou cerca de 17 genes da S. avermectinius responsáveis por codificarem as enzimas que estão envolvidas 
na biossíntese da avermectina, e classificar quais os genes responsáveis nas alterações ligadas ao anel de lactona (ECKHOLM,1989).

Em 2003, a equipe do Instituto Kitasato sequenciou o genoma do $S$. avermectinius, e essa análise permitiu a identificação do cluster gênico envolvido na produção de metabólitos secundários, esclarecendo a biologia da síntese de metabólitos secundários em nível genético (HORIKAWA et al., 2002; IKEDA et al., 2003).

A descoberta da ivermectina, desencadeou um grande impacto tanto na Medicina Veterinária e Humana, tendo esta descoberta proporcionado ao pesquisador Satoshi Ōmura o Prêmio Nobel do ano de 2015 na área de Fisiologia, que ele compartilhou com o parceiro colaborador na descoberta e desenvolvimento da droga, William Campbell, da Merck \& Co. Incorporated, além de ser prestigiado prêmio Gairdner Global Health Award de 2014 (DEL GIUDICE, 2016).

Hoje, a ivermectina continua a surpreender e motivar os cientistas com a perspectiva da melhoraria na saúde pública global tratando uma gama diversificada de doenças, com seu potencial inesperado de um agente endo e ectoparasitário e, até mesmo, novas descobertas no ramo na oncologia (JUAREZ; SCHCOLNIKCABRERA; DUEÑAS-GONZALEZ, 2018; ÕMURA, 2008)

\subsubsection{Mecanismo de ação da Ivermectina}

Como mencionado anteriormente, a ivermectina atua contra uma ampla gama de artrópodes, assim como atua como endo e ectoparasitário, e tem sido utilizada mais extensamente no tratamento de helmintos. Um dos mecanismos de ação elucidados, foi demonstrado em uma espécie de helminto Caenorhaditis elegans (um helminto de solo extensamente estudado na biologia dos eucariontes como um simples modelo de organismo) demonstrando que o fármaco atua na potencialização e ativação direta dos canais de cloreto regulados pelo glutamato nas membranas plasmáticas dos nematoides. Esse mecanismo acarreta na hiperpolarização das células neuromusculares e paralisia da faringe (GOLAN et al.2009). 
Figura 3 - Mecanismo de ação da Ivermectina

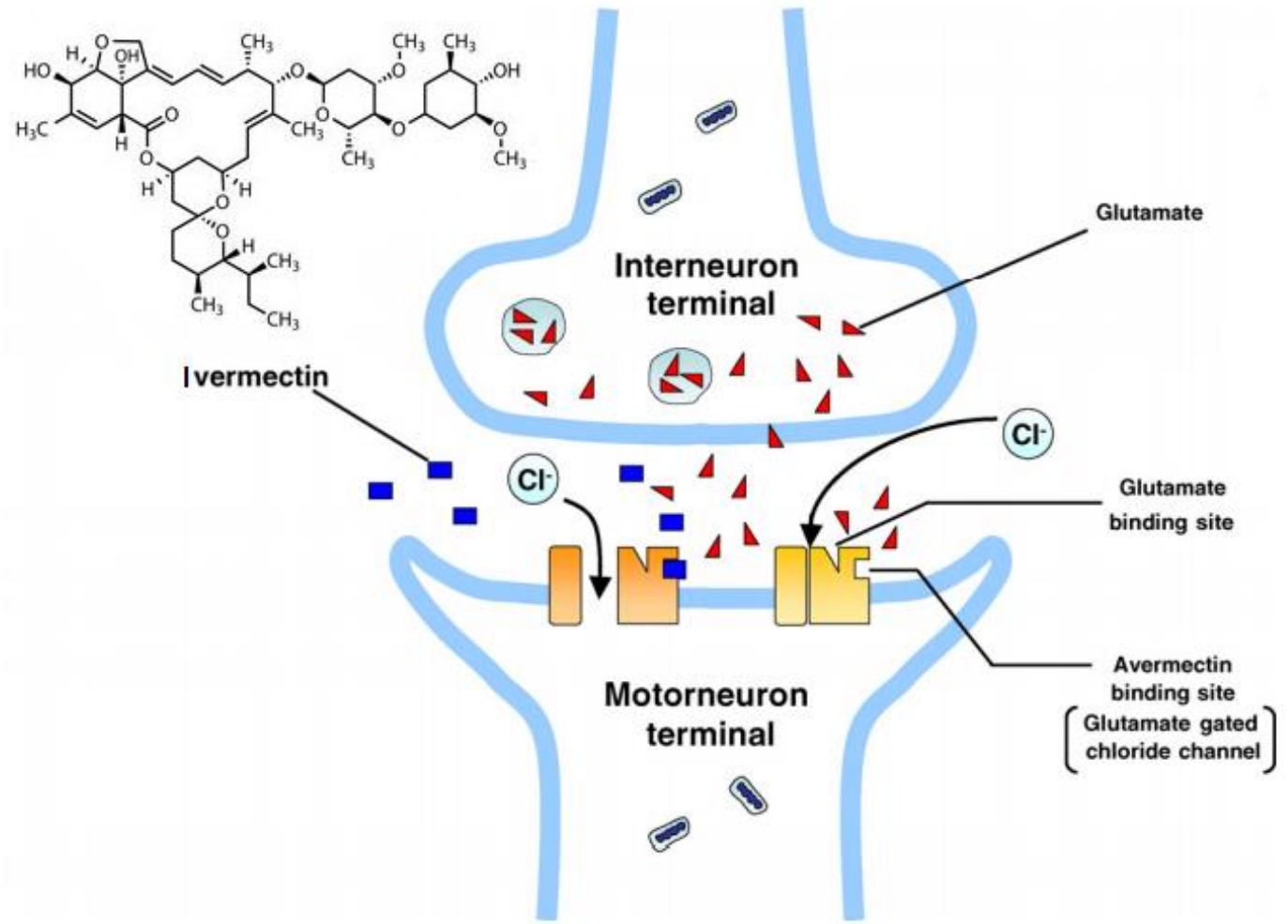

FONTE: Figura adaptada de S. Omura, 2008.

Outro mecanismo de ação que a ivermectina afeta, é na potencialização da ação inibitória do ácido gama-aminobutírico (GABA), desencadeando a hiperpolarização neuronal, permitindo a entrada dos íons cloro que irá resultar no bloqueio da transmissão nervosa (Figura 3). A ivermectina tem baixa interação com os receptores de GABA nos vertebrados, contudo nos invertebrados sua afinidade é cerca 100 vezes maior. Nos seres humanos os receptores de GABA são encontrados principalmente no SNC, e pela ivermectina ter alto peso molecular, faz com que não atravesse facilmente a barreira hematoencefálica, caracterizando um fármaco bem tolerado e seguro na medicina (BURG et al., 1979). 


\subsubsection{Mecanismo antitumorais da Ivermectina}

Com novas descobertas do reposicionamento farmacológico da ivermectina no âmbito da oncologia, estas vem impulsionando cada vez mais pesquisas visando conhecer os possíveis mecanismos envolvidos no efeito antitumoral e seu direcionamento para diversos tipos de neoplasias. Apesar dessa recém descoberta, alguns mecanismos moleculares possivelmente sejam alvo da ivermectina na remissão de tumores (JUAREZ; SCHCOLNIK-CABRERA; DUEÑAS-GONZALEZ, 2018).

Sabia-se que algumas linhagens de células tumorais, apresentam altos níveis de resistência e estão frequentemente associados à amplificação e superexpressão de um pequeno grupo de genes denominados MDR responsável pela expressão da glicoproteína-p (JUAREZ; SCHCOLNIK-CABRERA; DUEÑAS-GONZALEZ, 2018)

Em 1996 Didier e Loor provaram a capacidade de inibição da função da glicoproteína-P pela ivermectina, usando células de leucemia monocítica de murinos e leucemia linfocitica humana, células essas que apresentavam multirresistência a drogas. Este estudo baseou-se na medição da restauração da retenção de duas sondas em células multirresistentes (MDR), comparando o efeito da ivermectina com a ação da ciclosporina $A$ que é um potente agente com capacidade de reverter a resistência a múltiplos fármacos mediada por P-glicoproteína (Pgp) de células cancerígenas (DIDIER, 1996).

A ivermectina apareceu apenas algumas vezes mais fraca a ciclosporina $A$, mas mesmo assim mostrou-se eficaz ao reverter a resistência a múltiplos fármacos (DIDIER,1996).

Estudos in vivo realizados em camundongos portadores de carcinoma sólido de Ehrlich, com a variação da avermectina B1 mostram a capacidade de redução do crescimento tumoral em $50 \%$ no dia 5 na dose de $1 \mathrm{mg} / \mathrm{kg}$, sendo mais um passo para compreensão do potencial não explorado dessa classe de antiparasitário (DRINYAEV et al., 2004).

Outro mecanismo da ivermectina ainda pouco explorado, é sua ação sobre as mitocôndrias, onde o fármaco é capaz de inibir de maneira dose-dependente a taxa de consumo de oxigênio basal, diminuindo assim a atividade enzimática do complexo respiratório, ocasionando em alterações ligadas ao potencial de membrana e seu gradiente de prótons. Devido essa variação de gradiente, ocorre 
um aumento significativo do acúmulo de superóxido e diminuição do ATP na mitocôndria, o que induz uma disfunção mitocondrial e dano oxidativo (ZHU; LI; ZHOU, 2017).

Sua ação sobre a disfunção mitocondrial e dano oxidativo tem ligação não só com alterações na membrana, mas também, está ligado com diminuição da fosforilação da via Akt/ mTOR e da proteína S6 ribossômica (rS6) em U87, indicando uma possível inibição da via (ZHU; LI; ZHOU, 2017).

A via $A K T / m T O R$ está relacionada com a proliferação, síntese proteica, sobrevivência e motilidade das células, mutações nesta via têm sido associadas com o processo carcinogênico de diferentes tipos tumorais, de modo geral pesquisadores buscam alternativas para inibir essa via, e a ivermectina foi um dos compostos atuante na inibição das proteínas AKT, mTOR (ZHU; LI; ZHOU, 2017).

A ação da ivermectina é a capacidade de agir como um indutor de autofagia, ou seja, atua em uma via catabólica auto-degradativa mediada pelo proteassoma, uma protease dependente de ATP usada para destruir proteínas danificadas ou proteínas com erros de síntese, as quais são marcadas para degradação através da ligação de cadeias de proteínas conhecidas como ubiquitinas, mobilizando assim energia e nutrientes sob certos estímulos celulares devido a degradação e formação de novos peptídeos que serão reaproveitados (LEVINE; KROEMER, 2008; LIU et al., 2016).

Ao promover a ubiquitinação da quinase PAK1 (enzima responsável pela ativação de várias vias de sinalização que conduzem à regulação da expressão génica), e direcionar para a degradação no proteassoma, com a degradação da PAK1, consequentemente ocorre inibição da via Akt / mTOR, Ao mesmo tempo, a inibição da via AKT-MTOR induz subsequentemente a formação do complexo Ptdlns3K contendo BECN1, ambos relacionados com a indução de autofagia e reduz a função do regulador da apoptose Bcl-2 juntos, isso gera autofagia e apoptose, todos esse mecanismo já foi elucidado em células de cancer de ovário e glioblastoma (CRUMP, 2017; LEVINE; KROEMER, 2008; LIU et al., 2016).

Ainda assim, existem diversos outros mecanismo e vias que a ivermectina é capaz de atuar e abrangem uma gama de tumores nos quais seus efeitos vêm sendo testado (Tabela 1). 
Tabela 1 - Resumo de alvos antitumorais da ivermectina

\begin{tabular}{|c|c|c|}
\hline Alvo Molecular & Efeito & Referências \\
\hline Proteína MDR & Inibição & DIDIER; LOOR, 1996 \\
\hline Canal de cloreto & Aumenta a atividade & SHARMEEN et al., 2010 \\
\hline Via de Akt / mTOR & Inibição & LIU et al., 2016 \\
\hline Receptores P2X7 / P2X7 & Ativação & RAGANOV, et al.,2015; LEVINE, et al, 2008 \\
\hline Proteína PAK1 & Inibição & DOU et al., 2016; HASHIMOTO et al., 2009 \\
\hline Via WNT-TCF & Inibição & MELOTTI et al., 2014; SETH et al., 2016 \\
\hline Domínio SIN3 & Inibição & KWON et al., 2015 \\
\hline Helicase NS3 DDX23 & Inibição & YIN et al.,2015 \\
\hline Genes Nanog / Sox2 / Oct4 & Regulação negativa & DOMINGUEZ et al.,2018 \\
\hline
\end{tabular}

FONTE: JUAREZ et al., 2018.

\subsection{DOXORRUBICINA}

A doxorrubicina (DOX) é um inibidor da topoisomerase II e pertence à família das drogas antineoplásicas das antraciclinas, sendo um dos agentes farmacológicos mais potentes aprovados pelo FDA para o tratamento de diferentes tipos de tumores. Considerada um dos pilares da terapia antineoplásica por décadas, os esquemas convencionais de tratamento contendo antraciclinas demonstraram benefícios no tempo e na progressão dos tumores, e em termos de taxa de resposta e sobrevida geral (WINER et al., 2001).

As antraciclinas são antibióticos antitumorais naturais isolados de uma espécie de bactéria nomeada Streptomyces peucetius e sua descoberta foi no início da década de 60 (MINOTTI, 2004). A DOX é considerada um dos fármacos antineoplásicos com um amplo espectro de atividade e um dos mais potentes prescritos sozinho ou em combinação com outros agentes. De fato, a DOX é amplamente utilizada no tratamento de diversos tumores humanos como: sarcoma mieloblástico, leucemia linfoblástica, tumores sólidos e neoplasias hematológicas, incluindo mama, dutos biliares, próstata, útero, ovário, esôfago, estômago, tumores 
sólidos na infância, osteossarcomas, sarcomas e melanoma (DORASAMY et al., 2019).

No entanto, há uma grande escassez de estudos que empreguem a DOX em protocolos quimioterápicos veterinários para certas malignidades sendo seu uso baseado na sua eficácia contra neoplasias humanas. Entretanto, sua eficácia em cães pode não ser equivalente aos relatados em humanos, mesmo assim seu uso é bem difundido na área de saúde animal (ONG et al., 2017).

Em geral, após sua administração, cerca de 80 a $85 \%$ do fármaco se encontra conjugado as proteínas plasmáticas, mas sua concentração plasmática diminui rapidamente com a distribuição entre os tecidos, e seu tempo de meia-vida final é de 30 horas. A DOX sofre influxo de forma passiva pela membrana plasmática, mas também existem algumas proteínas transmembranas que são capazes de transportar, como a proteína SLC22A16 (GREENE et al., 1983). Já sua eliminação da célula depende de proteínas da família $A B C$ e RALBP1, sendo parte dessas proteínas que estão envolvidas no mecanismo de resistência a esse quimioterápico (BAO et al., 2012)

A nomenclatura IUPAC da DOX é (7S,9S)-7-[(2R,4S,5S,6S)-4-amino-5hidroxi-6-methiloxan-2-yl]oxi-6,9,11-trihidroxi-9-(2-hidroxiacetil)-4-methoxi-8,10dihidro-7H-tetracene-5,12-dione, e sua formula molecular $\mathrm{C}_{27} \mathrm{H}_{29} \mathrm{NO}_{11}$, de peso molecular 543,5193 g/mol (Figura 4).

Figura 4 - Molécula da Doxorrubicina

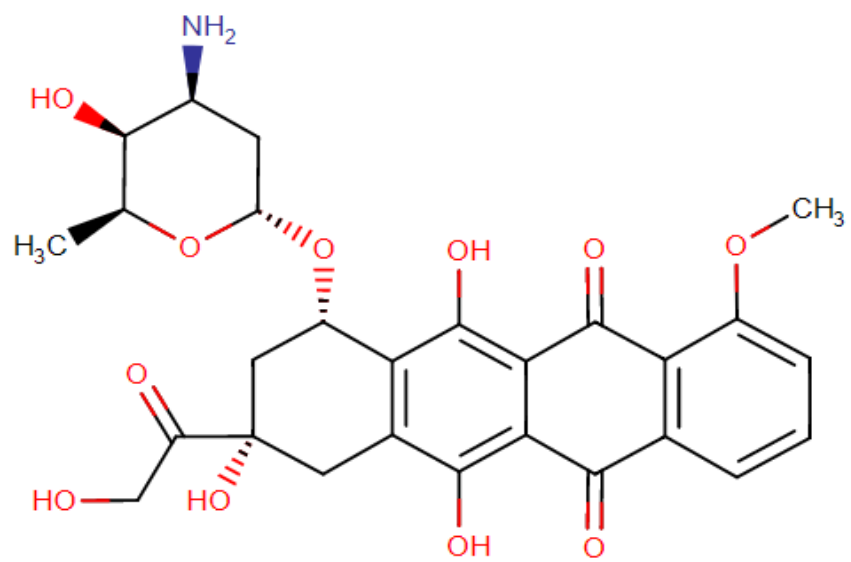

FONTE: LOWN, J.W. (1993). 
Sua molécula apresenta características lipofílicas e alta capacidade de se intercalar ao DNA, de maneira que sua concentração é cinquenta vezes mais elevada no núcleo do que no citosol. A DOX sofre metabolização intensa no fígado e tem como principal via de excreção o sistema hepatobiliar, mas também sofre excreção urinária (TAKANASHI e BACHUR, 1976).

\subsubsection{Mecanismo de ação da Doxorrubicina}

A atividade antitumoral da DOX é atribuída à sua capacidade de se intercalar na dupla hélice do DNA, podendo ligar-se covalentemente as proteínas envolvidas na replicação do DNA e em enzimas de transcrição. Sua ação preponderante é sobre a enzima nuclear topoisomerase II, que irá resultar na inibição da síntese de DNA, RNA e na formação de proteínas, desencadeando mecanismos que levam a morte celular (MINOTTI, 2004). Além dessa via intra DNA, os pesquisadores Ashley e Poulton, identificaram com a ajuda de um corante fluorescente de DNA PicoGreen, que as antraciclinas se intercalaram não apenas com o DNA nuclear, mas também com o DNA mitocondrial (mtDNA)(ASHLEY; POULTON, 2009).

A família de enzimas topoisomerases são enzimas nucleares que controlam e modificam o estado topológico do DNA. Estas enzimas nucleares são classificadas em tipo I e II, de acordo com seus mecanismos e propriedades físicas nas células. A topoisomerase II (Topo II) está mais ligada ao mecanismo de ação da DOX, a mesma existe nas isoformas $\alpha$ ou $\beta$, e é responsável pela quebra da dupla fita de DNA, promovendo a quebra transitória de ligações fosfodiéster, desencadeando eventos como liberação da fita de DNA enovelada, além de auxiliar a conformação da fita, evitando as supertorções, possibilitando a execução desses processos celulares sem danos a fita de DNA (SAMPAIO et al., 2006;HANDE, 2008). As topoisomerases durante a proliferação celular participam da manutenção e replicação do DNA, em geral as células cancerígenas possuem uma maior concentração de topoisomerases, acarretando um aumento da replicação dessas células, e diferentemente das células normais, as células cancerígenas tem checkpoints defeituosos (KELLNER; PARWARESCH, 2000). 
Assim, as topoisomerases são alvos importantes no desenvolvimento de novas drogas, principalmente para as que apresentam atividade antineoplásica (De Vita JR et al., 1997).

O modelo mais representativo para a ação da DOX envolve o bloqueio da topoisomerase II, resultando em quebras de DNA de cadeia dupla e morte celular (BURGESS et al., 2008).

Fármacos intitulados como "veneno de topoisomerase II", atuam como armadilhas nos locais de quebra realizados pela topoisomerase II, estabilizam 0 complexo de clivagem e impede o religamento das fitas de DNA. A hipótese de que a DOX funciona de forma semelhante, bloqueando a topoisomerase II nos locais de quebra, estabiliza o complexo de clivagem e impedindo a resselagem do DNA, isso desencadeia diversos mecanismos pró apoptóticos nas células. Já foi demonstrado em um modelo de linfoma em camundongos onde os níveis de topoisomerase II determinam a eficácia do tratamento com doxorrubicina (BURGESS et al., 2008).

Outros mecanismos ainda estudados, é capacidade de promover o aumento de espécies reativas de oxigênio (EROS) através de sua interação com $\mathrm{Fe}^{3+} \mathrm{e}$ desregulação do óxido nítrico (NO). Com o aumento de EROS gera o estresse oxidativo levando a danos no DNA e a ativação de mecanismos apoptóticos, como a via de interação das proteínas p53 e ativação da sinalização intrínseca das caspases (MINOTTI, 2004).

\subsection{MECANISMO DE RESISTÊNCIA A MÚLTIPLAS DROGAS MEDIADA PELA GLICOPROTEÍNA-P NO CENÁRIO DA ONCOLOGIA}

$\mathrm{Na}$ medicina atual, podemos atribuir uma das principais causas do insucesso do tratamento farmacológico de neoplasias, à expressão de transportadores transmembrânicos ou conhecidos também como bomba de efluxo. A resistência a múltiplas drogas conhecida pela sigla (MDR) é um caso de resistência adquirida, observada em células tumorais, que consiste na ausência ou diminuição da resposta aos quimioterápicos (HILL, 1996).

Existem diversos fatores que podem desencadear o MDR, sendo um dos principais e mais conhecidos, o transporte da droga pela membrana plasmática e sua expulsão por proteínas transmembranas, alterações no metabolismo da droga pelas células, aumento na reparação de DNA podendo ocasionar na incapacidade 
de sofrer apoptose, alterações de expressão de receptores da célula tumorais. Dentre estes, o primeiro é o principal mecanismo relacionado com a resistência aos fármacos, em geral esses transportadores de efluxo de drogas, pertencem a família de cassetes (ABC) ATP-dependentes, sendo a Glicoproteína P (Gp-P) umas das proteínas identificadas como um produto do gene de multirresistência aos fármacos. O mecanismo mais comum de MDR é a superexpressão de Gp-P na membrana das células tumorais. A Gp-P está presente em diversas células dos tecidos normais como o fígado, cérebro, intestino, placenta, rim dentre outros, onde desempenha a função de expulsão de xenobióticos e compostos tóxicos das células, atuando como um modo de defesa da mesma, sendo que esta capacidade de defesa é capaz de atuar contra os fármacos (NANAYAKKARA et al., 2018).

A glicoproteína-P (Gp-P / ABCB1) é uma proteína transmembrana glicosilada de peso molecular de 170-kDa, codificada pelo gene MDR1 e é a bomba de efusão mais bem estudada da família dos transportadores $A B C$ que atualmente é composto por 48 membros, que compartilham sequências e homologia estrutural. A mesma é constituída por duas subunidades, dois domínios hidrofóbicos, que incluem 12 segmentos transmembranares $\alpha$-hélices que formam os domínios de ligação do fármaco (DBD) e estão envolvidas no transporte de toxinas e xenobióticos para fora da célula. E os outros dois domínios de ligação de nucleotídeos na região citoplasmática que são responsáveis pelo acoplamento da hidrólise do ATP ao processo de transporte (HIGGINS, 1994; JULIANO; LING, 1976).

No ano de 1994, Higgins e Stein propuseram, o possível mecanismo de funcionamento da P-gp sendo atualmente, o modelo mais aceito ilustrado na Figura 5, cuja droga adentra a bicamada lipídica, e por afinidade lipofílica migra para a região interna da proteína, chamada de "folheto interno", entrando em um bolsão que constitui o sítio ligante. O ATP liga-se a fração NBD (sítio de ligação de nucleotídeo), fornece energia na quebra por hidrólise de ATP para ADP, para que ocorra uma mudança conformacional, expondo o sítio ligante para o lado extracelular, desse modo a droga é expulsa de dentro da célula (HIGGINS, 1994). Esta representação do mecanismo de funcionamento, é atribuída a maiorias das proteínas transportadoras pertencentes à superfamília $A B C$ com ressalva de apenas algumas variações (DAWSON; LOCHER, 2006; LITMAN et al., 2001).

No ano de 1989, LAl et. al identificou o aumento dos níveis de RNA do gene MDR1, em diversos pacientes com tumores distintos, sendo o gene MDR1 
responsável pela codificação da glicoproteína-P em cancros humanos, mostrando que as células tumorais apresentam aumento da expressão de Gp-P na membrana, e também correlacionou esse aumento dos níveis de MDR1 com os tumores intrinsecamente resistentes a medicamentos (LAl et al., 1989).

A superexpressão da Gp-P em tumores leva a redução do acúmulo de quimioterápicos e a resistência contra uma gama de fármacos disponíveis, tais como a vinblastina e antraciclinas (doxorubicina) e até mesmo alguns outros fármacos fora da classe dos quimioterápicos (SAFA, 1999).

Figura 5 - Mecanismo de funcionamento da glicoproteína-P (Gp-P), mostrando a função normal da Gp-p na membrana plasmática de uma célula cancerígena durante o efluxo de um fármaco. A ativação da bomba de efluxo pela hidrólise de uma molécula de ATP ligada conduz as moléculas do fármaco citotóxico para fora da célula

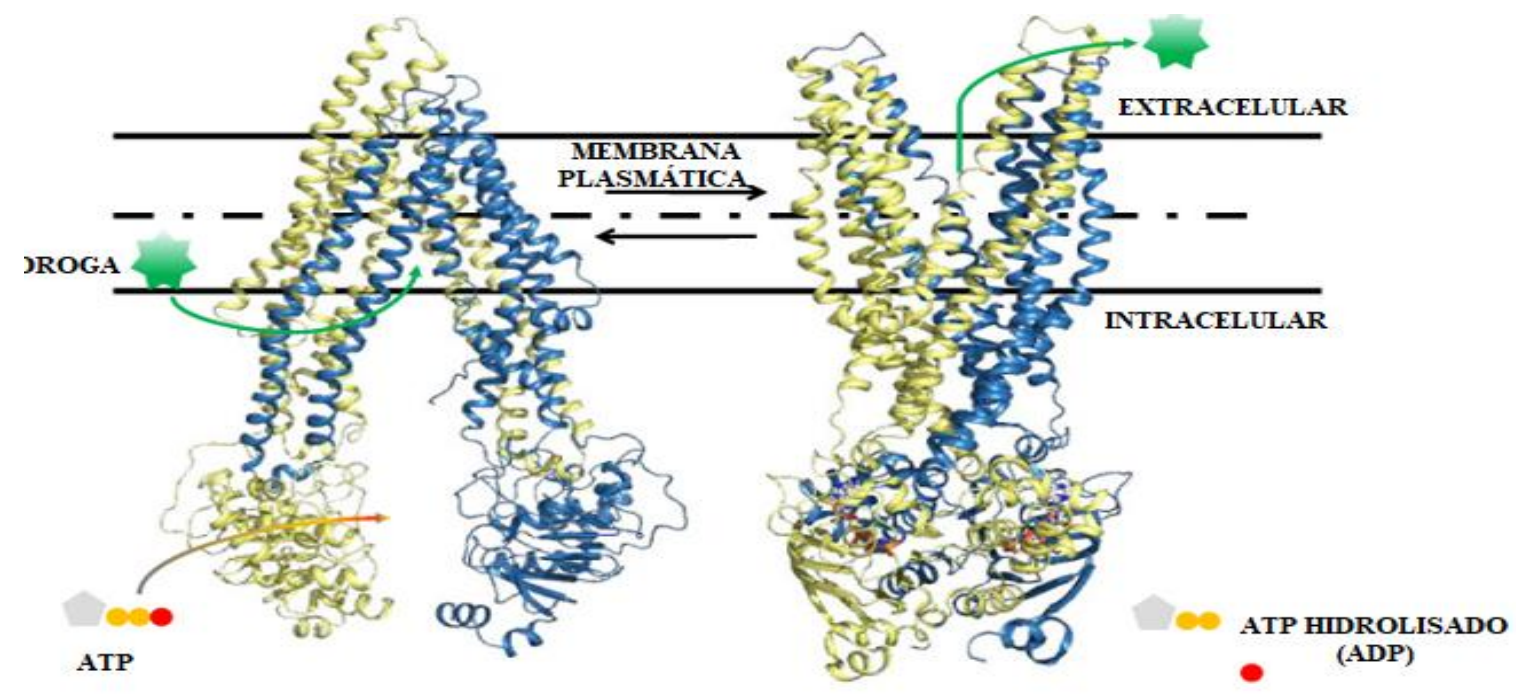

FONTE: (LOO; CLARKE, 2016).

Pesquisas envolvendo estrutura atividade de fármacos com propriedades lipofílicas, devido a presença de um ou mais anéis aromáticos planares e uma carga catiônica, são comuns à maioria dos agentes reversores de MDR (ZAMORA; PEARCE; BECK, 1988).

O estudo de Pouliot e seu grupo, apresentam evidências da capacidade da ivermectina (IVM) ser um fármaco reversor de MDR e os resultados provenientes deste estudo mostraram que a IVM interage diretamente com o sítio de ligação da Gp-p devido suas características físico-químicas, saturando o mesmo e permitindo 
que outros fármacos adentrem na célula sem que esse sistema seja capaz de eliminar (POULIOT et al., 1997).

No ano de 1994, Schinkel et al, criou um modelo de camundongo com deficiência no gene Mdr1a, realizando o rompimento desse gene, utilizando um vetor direcionado, no qual um fragmento genômico Nhel de 1,6 kb contendo os exons $6 \mathrm{e}$ 7 foram substituídos por um cassete de fosfotransferase, fazendo com que os descendentes dos camundongos modificados, não expressassem corretamente o gene Mdr1a e, consequentemente, não codificando a Gp-p nos domínios transmembrana das células(SCHINKEL et al., 1994)

Baseado nesse fundamento, o estudo procedeu-se com a utilização da IVM nesses camundongos modificados, onde sugeriu que ela pode ser um substrato para a Gp-p, uma vez que o rompimento do gene Mdr1a da Gp-p murina levando ao acúmulo da droga no cérebro e outros tecidos que superexpressam intrinsecamente a Gp-p (SCHINKEL et al., 1994).

Outro fato importante a salientar é a extrema sensibilidade à IVM usualmente relatada em alguns cães da raça Collie. A dose letal por via oral foi de aproximadamente $0,4 \mathrm{mg} / \mathrm{kg}$ em Collies, ao contrário de aproximadamente 80 $\mathrm{mg} / \mathrm{kg}$ em cães normais. Essa hipersensibilidade foi associada ao acúmulo de IVM no cérebro, tento uma analogia diretamente correlacionada a uma deficiência genética similar em uma glicoproteína $P$ do tipo mdr1(PULLIAM ,1985).

A partir desses resultados promissores, encontrou-se uma relação ao buscar associações farmacológicas entre a IVM e quimioterápicos cujo efeito isolado não apresentava mais eficácia. Furusawa et. al (2000), buscou através de seu estudo, a associação da IVM e a DOX, pleiteando e mostrando que essa associação foi capaz de aumentar a apoptose de células de leucemia (P388) resistentes à DOX. Nesse estudo, foi demonstrado que a presença da IVM é capaz de induzir um aumento da sensibilidade das células à DOX, ocasionado pela mudança potencial de membrana plasmática nas células resistentes à este quimioterápico, auxiliando a mesma a adentrar nas células e, consequentemente, gerar um aumento de morte celular (FURUSAWA et al., 2000). 


\subsection{MELANOMA}

Os melanomas são neoplasias de origem melanócitica e melanoblástica, células essas, responsáveis por produzirem melanina e de origem embrionária no neuroectoderma. Como característica, os melanomas podem ser encontrados em qualquer localização anatômica onde existam acúmulos de melanócitos (GOLDSCHMIDT; GOLDSCHMIDT, 2016).

Atualmente a prevalência dessa neoplasia em cães tem aumentado consideravelmente e a crescente incidência das afecções nessa espécie tem inúmeras razões, entre elas, a maior longevidade observada nestes animais, tornando-se um grande desafio tanto para o diagnóstico como para o tratamento desta neoplasia (DE NARDI et al., 2002).

O melanoma é frequentemente relatado em cães e mais raramente em outras espécies como gatos e animais selvagens (NISHIYA et al., 2016). Os humanos também são acometidos e, neste sentido, os modelos animais e in vitro são muitas vezes utilizados como principal componente para testes de novos tratamentos para o melanoma, visto que esta neoplasia apresenta caráter agressivo, além de ser um dos mais frequentes tumores de pele (STARKEY et al., 2005)

O melanoma canino representa de 4 a $7 \%$ de todos os tumores e 9 a $20 \%$ de todas as neoplasias cutâneas (MODIANO; RITT; WOJCIESZYN, 1999).O mesmo origina-se dos melanócitos, podendo acometer diversas regiões, dentre elas: a cavidade oral (56\%), lábios (23\%), pele (11\%) e dedos ( $8 \%)$, e até mesmo os olhos que representam 2\%. As metástases são encontradas em cerca de $60 \%$ dos melanomas orais, $40 \%$ dos melanomas em dígitos e $12 \%$ dos melanomas cutâneos(SMITH, GOLDSCHMIDT, 2002).

Comumente são classificados em malignos ou benignos, mas, geralmente, possuem prognóstico desfavorável. Melanomas possuem uma característica predominantemente invasiva, e estão frequentemente associados com metástase (CARLON, W., MCGAVIN, M, 1998). Na maioria dos casos, quando se diagnostica melanoma canino de origem maligna, alguns poucos meses após a cirurgia de excisão, ocorre a morte do animal em decorrência de complicações relacionadas à metástase, ou seja, o prognóstico do melanoma maligno é ruim e a taxa de sobrevivência é inferior a um ano em cerca de 10\% dos casos (DAHME e WEISS 1989; STEPHEN et al., 1998). 
A etiologia do melanoma em humanos é bem elucidada, e uma das principais causas do desenvolvimento dessa neoplasia é a exposição aos raios ultravioletas do sol, sendo que a radiação UV é capaz de produzir lesões nas bases nitrogenadas e quebra no esqueleto de açúcar-fosfato do ácido desoxirribonucleico (DNA), além de induzir alterações na expressão gênica como parte da resposta ao estresse oxidativo celular. Outro fator é o componente genético, por meio de alterações transmitidas aos descendentes (KUFE et al., 2003).

Diferentemente da etiologia em humanos, o melanoma em cães não apresenta uma base etiológica bem elucidada, alguns estudos apontam predisposição genética associadas a mutações genéticas em genes supressores de tumores e genes que controlam a apoptose no melanócitos neoplásicos, além de outros fatores como a exposição a agentes químicos e trauma (MODIANO; RITT; WOJCIESZYN, 1999; S. H. SMITH, M. H. GOLDSCHMIDT, 2002).

O melanoma, em especial na sua forma maligna é considerado altamente resistente a uma ampla variedade de agentes quimioterápicos, e essa resistência como mencionado anteriormente, pode ser mediada por várias proteínas com diferentes mecanismos de ação, dentre elas, a Gp-P, o produto do gene MDR-1 (CHARTRAIN et al., 2012).

Primeiramente detectada em tecidos derivados da linhagem neuroectodérmica, incluindo células progenitoras de melanócitos, no melanoma, as células que expressam as proteínas da família ABCB5 são dotadas de capacidade de autorrenovação, diferenciação e tumorigenicidade (KESHET et al., 2008).

A expressão da Gp-p em amostras clínicas de melanoma tanto humano como canino correlaciona-se positivamente com a progressão neoplásica, sugerindo que a expressão desta proteína está associada à agressividade do tumor e a capacidade de expulsar os fármacos (CHARTRAIN et al., 2012; FINOTELLO et al., 2017).

Existe uma variabilidade da expressão da Gp-p dependendo da localização anatômica do melanoma. Investigações pela técnica de imuno-histoquímica em melanoma canino oral, apresentaram uma alta taxa de expressão da Gp-p na membrana celular em cerca $100 \%$ das amostras dos tumores, já os tumores cutâneos apresentaram $66,6 \%$ e esses resultados corroboram com o fato da similaridade dos melanomas em cães e humanos, representando um histórico onde esses tumores são capazes de desencadear o MDR (FINOTELLO et al., 2017). 


\section{OBJETIVOS}

\subsection{OBJETIVO GERAL}

Investigar os efeitos citotóxicos da associação de Doxorrubicina com Ivermectina em um modelo celular in vitro em uma linhagem celular de melanoma canino.

\subsection{OBJETIVOS ESPECÍFICOS}

$\checkmark$ Caracterização da linhagem celular de Melanoma Canino:

-Tempo de duplicação, ciclo celular, imunoistoquímica para os marcadores Melan A e PNL-2, histologia e morfologia);

$\checkmark$ Tratamento das culturas celulares esferoides de melanoma canino em diferentes concentrações com Ivermectina $(0,5 \mathrm{mM} ; 1,25 \mathrm{mM} ; 2,5 \mathrm{mM})$ e Doxorrubicina $(0,5 \mu \mathrm{M})$ e a associação dos fármacos durante 48 horas para: 1- avaliar a citotoxicidade celular; 2- avaliar o perfil de morte celular (apoptose e necrose); 3- avaliar os efeitos do tratamento sobre o ciclo celular; 4- avaliar os efeitos sobre migração celular pós tratamento. 


\section{MATERIAIS E MÉTODOS}

\subsection{OBTENÇÃO E CARACTERIZAÇÃO DA LINHAGEM DE MELANOMA CANINO}

\subsubsection{Obtenção da linhagem de melanoma}

Foi utilizada uma linhagem de células de melanoma canino primário extraído de um linfonodo metastático de um cão macho de 13 anos, obtido de uma amostra doada pelo Hospital Veterinário de Botafogo (RJ), e processado no Laboratório de Farmacologia Aplicada e Toxicologia (LADTOx) da Faculdade de Medicina Veterinária e Zootecnia da Universidade de São Paulo a qual foi denominada MeLn. O processamento deste linfonodo acometido pelo melanoma foi obtido por meio de fragmentos fracionados com o auxílio de um bisturi e dissociados mecanicamente com um êmbolo de seringa de $5 \mathrm{~mL}$ e filtrados em malha de nylon de $70 \mu \mathrm{m}$.

Em seguida, foi avaliado a viabilidade e a quantificação das células pelo método de exclusão por azul de Tripan. As células viáveis foram mantidas em meio de cultura de Eagle modificado por Dulbecco (DMEM), suplementado com 10\% de soro fetal bovino (SFB) (Gibco), e $10 \mu \mathrm{g} / \mathrm{ml}$ de penicilina/estreptomicina (Sigma) em em frascos de cultivo celular (com área de $25 \mathrm{~cm}^{2}$ ). A linhagem foi mantida em estufa a $37{ }^{\circ} \mathrm{C}$ e com condições atmosféricas de $5 \%$ de dióxido de carbono $\left(\mathrm{CO}_{2}\right)$ até que as células arranjadas em monocamada fossem submetidas a uma dissociação enzimática com uma solução de tripsina+EDTA (0,25\%) (tripsinisação) que permitisse a eliminação da maioria dos fibroblastos. A tripsinisação foi neutralizada com DMEM suplementado com $10 \%$ de SFB. Ao longo do cultivo celular foram realizadas observações da morfologia sob microscopia de contraste de luz e avaliação da mesma até a $5^{\mathrm{a}}$ passagem.

\subsubsection{Imuno-histoquimica (Mela-A e PNL-2)}

A análise imuno-histoquímica foi realizada para confirmar a histogênese das células tumorais. Para tanto, o material emblocado foi enviado ao Laboratório particular Vetmol (Botucatu-SP) para realização da técnica de imuno-histoquímica utilizando os anticorpos primários de anti-Melan-A (clone A103, 1:100; ImPath) e anti-PNL-2 (clone PNL-2, 1:100, Sigma). 


\subsubsection{Análise de ciclo celular}

As fases do ciclo celular são caracterizadas por variações no seu conteúdo de DNA, onde a análise por citometria de fluxo após marcação com iodeto de propídeo $(\mathrm{PI})$, possibilita a quantificação de cada fase do ciclo celular presente nas células.

As células $\left(3 \times 10^{6}\right.$ células/poço) foram semeadas em placas de 96 poços durante 24 e 48 horas. Em seguida, as células foram fixadas em etanol $90 \%$ e coradas com solução de iodeto de propídeo (PI) e RNAse. A marcação fluorescente do DNA pelo PI permite a determinação das fases do ciclo celular por citometria de fluxo (modelo FACSCalibur-BD). A análise foi realizada por meio do software FlowJO versão 10.

\subsubsection{Tempo de duplicação}

O tempo de geração ou duplicação de uma célula é definido como o tempo necessário para que ocorra a duplicação dessa célula e formação de uma outra nova célula.

Para esse teste, as células foram mantidas em cultivo em frascos de cultivo celular (com área de $25 \mathrm{~cm}^{2}$ ), em meio DMEM com $10 \%(\mathrm{v} / \mathrm{v})$ de soro fetal bovino, e cultivadas a $37^{\circ} \mathrm{C}$ em atmosfera de $5 \%$ de $\mathrm{CO}_{2}$, sendo que cada garrafa foi mantida com uma confluência de $0,5 \times 10^{6} / \mathrm{ml}$ e 1,5x 106/ml. Ao longo do cultivo celular foram realizadas observações e fotomicrografias nos tempos 0h, 24h, 48h, $72 \mathrm{~h}$ e 96 horas, de um campo demarcado no frasco de cultura, as fotomicrografias foram avaliadas por meio do programa MacBiophotonics ImageJ para realização da contagem das células. Após a contagem das células, os valores obtidos foram calculados com o auxílio da calculadora Doubling Time (http://www.doublingtime.com/compute_more.php), avaliando o tempo de duplicação das células em uma série de tempo. 


\subsection{TRATAMENTO COM AS ASSOCIAÇÕES FARMACOLÓGICAS.}

\subsubsection{Preparação da ivermectina}

Para o ensaio foi utilizado o padrão secundário de Ivermecina (Hebei Veyong Animal Pharmaceutical Co., Ltda.) para excluir possíveis variáveis oriundas dos excipientes utilizados na formulação comercial. A partir de uma solução estoque de ivermectina $100 \mathrm{mM}$ em DMSO, realizou-se diluições em água ultrapura para obtenção da molaridade do fármaco desejada em cada poço. A molaridade variou de $0,5 \mathrm{mM}, 1,5 \mathrm{mM}$ e 2,5 mM. O volume utilizado da solução de ivermectina foi de $1 \mathrm{uL}$ por poço da placa de 24 poços. As concentrações de ivermectina foram previamente testas em estudos preliminares realizados in vitro pelo nosso grupo de pesquisa, no qual foram observados efeito citotóxicos na metade da dose usual plasmática ( $5 \mathrm{mM})$ (dados ainda não publicados).

\subsubsection{Preparação da Doxorrubicina}

Para o ensaio foi utilizado cloridrato de doxorrubicina (FAULDOXO®) Libbs Farmacêutica Ltda, apresentação em solução injetável de $50 \mathrm{mg}$ em embalagem com 1 frasco-ampola), foi feita uma solução com diluição em tampão fosfato (PBS) para concentração desejada $(0,5 \mu \mathrm{M})$. As doses de doxorrubicina foram previamente testas em estudos preliminares in vitro realizados pelo grupo de pesquisa do laboratório e baseado em achados na literatura, no qual observaram efeito citotóxico na metade da dose usual plasmática ( $2 \mu \mathrm{M}$ ) (Dados ainda não publicados; LI et al 2019).

\subsubsection{Cultivo tridimensional de melanoma canino}

As células de melanoma canino (MeLn) foram mantidas em cultivo em monocamadas em frascos de cultivo celular (com área de $25 \mathrm{~cm}^{2}$ ), em meio DMEM com $10 \%(\mathrm{v} / \mathrm{v})$ de soro fetal bovino, até atingirem sub confluência de $80 \%$ da capacidade da garrafa. Após tripsinização cerca de $2 \times 10^{6}$ das células de melanoma foram plaqueadas em duas placas de 24 poços, sendo adicionado $2 \mathrm{ml}$ do meio AIM $\mathrm{V}$ Serum Free Medium, e mantidas em estufa a $37^{\circ} \mathrm{C}$ e com condições atmosféricas de $5 \%$ de dióxido de carbono $\left(\mathrm{CO}_{2}\right)$, durante 24 horas antes do 
tratamento. Após 24 horas, foi observado por microscopia que o meio AIM V Serum Free Medium, foi capaz de modificar o perfil das células para um arranjo tridimensional também conhecido como esferoides (agregado celular).

\subsubsection{Tratamento células tumorais (MeLn)}

A linhagem foi semeada na densidade de 2,0 ×106 células/poço, em duas placas de 24 poços e sua adesão ocorreu ao longo de 24 horas em estufa a $37^{\circ} \mathrm{C}$ com $5 \%$ de $\mathrm{CO}_{2}$. Em seguida, o poço utilizado como controle continha apenas as células com o meio AIM V Serum Free Medium, nos outros poços foram adicionados $1 \mu \mathrm{l}$ dos seguintes tratamentos: Controle (células sem tratamento), dimetilsulfóxido (DMSO), ivermectina nas concentrações $(0,5 \mathrm{mM}$; 1,25 mM; 2,5 mM) e Doxorrubicina $(0,5 \mu \mathrm{M})$, e a associação entre ivermectina e

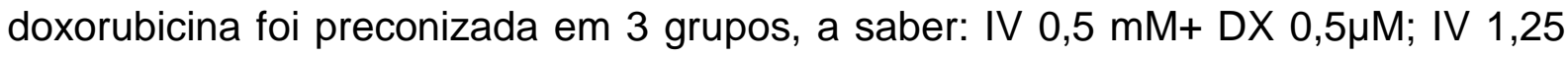
$\mathrm{mM}+\mathrm{DX} 0,5 \mu \mathrm{M}$ e IV 2,5 mM+ DX 0,5 $\mu \mathrm{M}$. As células foram incubadas por 48 horas. Ao término da incubação, o sobrenadante (meio de cultura) foi coletado em tubo de citometria, as células foram lavadas com $1 \mathrm{~mL}$ de tampão PBS 1X. Para facilitar a leitura de morte celular, foi adicionado $100 \mu \mathrm{L}$ de tripsina 0,25\% para que ocorresse a desfragmentação das células de esferas para células individuais. A ação da tripsina foi interrompida com $250 \mu \mathrm{L}$ de PBS $1 \times$ contendo $10 \%$ de soro fetal bovino. As quadruplicatas foram recolhidas e adicionadas em um único tubo de citometria de fluxo. Em seguida, foram centrifugadas por 5 minutos a $160 \times$ g; o sobrenadante foi descartado e o pellet de células foi ressuspendido em 250 ul de uma solução contendo PBS $1 \mathrm{X}$ e iodeto de Propídio (PI). Após 15 minutos de incubação, procedeu-se a leitura das células em citômetro de fluxo (FACSCalibur) e para análise de dados foi utilizado o software (FlowJo X).

\subsubsection{Análise do Mecanismo de Morte Celular: ensaio de apoptose e necrose (Anexina V-FITC/lodeto de Propídeo)}

O ensaio de detecção de apoptose e necrose por meio dos reagentes Anexina V-FITC e lodeto de Propídeo baseia-se na ligação da anexina V-FITC à fosfatidilserina presente na membrama das células que estão iniciando o processo 
apoptótico, e o lodeto de Propídeo é uma molécula que se intercala no DNA, desde que a membrana celular esteja permeável, e devido ao seu auto peso molecular não são passíveis de penetrar na célula intacta, bem como não marcam células apoptóticas sem que estas apresentem alterações na permeabilidade da membrana plasmática, como ocorre nos estágios finais da apoptose. Para esse ensaio utilizouse o Kit de detecção de apoptose Anexina V-FITC/lodeto (PI) (BD, Biosciences), onde cerca de $2 \times 10^{6}$ das células de melanoma foram plaqueadas em duas placas de 24 poços, sendo adicionado $2 \mathrm{ml}$ do meio AIM $V$ Serum Free Medium, e mantidas em estufa a $37{ }^{\circ} \mathrm{C}$ e com condições atmosféricas de $5 \%$ de dióxido de carbono $\left(\mathrm{CO}_{2}\right)$, durante 24 horas antes do tratamento. $\mathrm{O}$ tratamento foi realizado e as células foram incubadas por 48 horas. Ao término da incubação, o sobrenadante (meio de cultura) foi coletado em tubo de citometria, as células foram lavadas com 1 $\mathrm{mL}$ de tampão PBS 1X. O mesmo procedimento de desfragmentação dos esferoides foi realizado com a adição de $100 \mu \mathrm{L}$ de tripsina 0,25\% e a ação da tripsina foi interrompida com $250 \mu \mathrm{L}$ de DMEM com 10\% de soro fetal bovino. Após lavagem das células em PBS, o sobrenadante foi descartado e ao pellet celular foi adicionado $200 \mu \mathrm{L}$ de tampão anexina e em seguida acrescentado $5 \mu \mathrm{L}$ de Anexina V-FITC e 1 $\mu \mathrm{L}$ de iodeto de propídio. Os tubos controle foram utilizados para calibração do aparelho, onde, foi colocado um tubo apenas com anexina, outro com o iodeto de propídio e um terceiro com os dois agentes. As células foram incubadas em temperatura ambiente por 15 min na ausência de luz, e posteriormente foi feito à aquisição dos dados em citômetro de fluxo (modelo FACSCalibur-BD). Para análise de dados foi utilizado o software (FlowJo X).

Foi utilizado a classificação como células em apoptose inicial aquelas com marcação somente para Anexina-V $(\mathrm{An+})$ / (PI-), e como células em apoptose tardia aquelas com dupla marcação de Anexina e $\mathrm{PI}(\mathrm{An}+) /(\mathrm{PI}+)$.

\subsubsection{Ensaio de Migração celular- Método de Wound Healing}

As células utilizam o processo de migração no organismo tanto em condições fisiológicas, bem como em situações patológicas, onde no processo metastático as células tumorais migram do tumor primário para o sistema circulatório e se estabelecem em um novo local (YAMAGUCHIA; CONDEELISA, 2008). 
O potencial migratório das células Meln, foi avaliado através do ensaio de migração em monocamada, utilizando o método "wound healing", baseado na criação de uma falha na monocamada celular ("ferida"), como descrito por Liang et al. (2007). Para isso, cerca de 2,0 × $10^{6}$ células/poço foram semeadas em placas de 12 poços e mantidas por 24 horas até formarem uma monocamada confluente. Em seguida, a falha foi confeccionada com auxílio de uma ponteira estéril de $200 \mu \mathrm{L}$ (Figura 6), as culturas foram lavadas 1 vez com PBS para a remoção dos debris celulares, após a lavagem, iniciou a aplicação dos tratamentos e suas associações, permanecendo apenas o grupo controle sem o tratamento, logo após o tratamento as mesmas foram incubadas em estufa a $37^{\circ} \mathrm{C}$ em atmosfera de $5 \%$ de $\mathrm{CO}_{2}$.

Figura 6 - Ilustração da técnica de Wound Healing
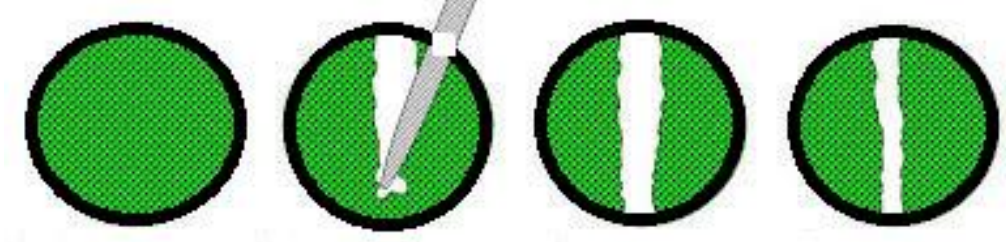

Fonte: Modificado a partir de (HULKOWER; HERBER, 2011).

Foram realizadas fotomicrografias em microscópio com contraste de fase nos tempos 0, 24 e 48 horas; foi delimitada com a caneta na parte inferior da placa a área exata para tirar as fotomicrografias durante os 3 períodos, sem haver variação de local. A área de fechamento da falha pela migração celular foi medida através do software ImageJ e o percentual de fechamento foi calculada utilizando a seguinte equação, descrita por(YUE et al., 2010):

$$
\% \text { de fechamento }=\frac{\left(A_{t=0 h}-A_{t=\Delta h}\right)}{\left(A_{t=0 h}\right)} x(100)
$$

Sendo At $=$ Oh é a medida da área da falha imediatamente após sua realização e At $=\Delta h$ é a medida da área da falha após 24 ou 48 horas de incubação com os fármacos. 


\subsubsection{Análise do ciclo celular pós tratamento}

Para esta análise $\left(3 \times 10^{6}\right.$ células/poço) foram semeadas em placas de 24 poços e mantidas na estufa a $37^{\circ} \mathrm{C}$ em 5\% de $\mathrm{CO}_{2}$ durante 24 horas. Após as 24 horas foi realizado o tratamento com os fármacos e mantidas na estufa por 48 horas pós tratamento. Após o período de tratamento as células foram coletadas, lavadas com PBS estéril e mantidas durante 2 horas no álcool etílico para fixação. Em seguida as células foram lavadas e centrifugadas 4 vezes em PBS para retirada do álcool etílico. As mesmas foram coradas com solução de iodeto de propídeo (PI) e RNAse. A marcação fluorescente do DNA pelo PI permitiu a determinação das fases do ciclo celular por citometria de fluxo quando analisadas no algoritmo de ciclo celular do software FlowJo.

\subsection{ANÁLISE ESTATÍSTICA}

Antes de aplicar-se a análise estatística foi verificado por meio do teste de Bartlett qual tipo de teste-parametrico ou não-parametrico, foi o mais adequado para cada dado. As médias e os desvios padrões obtidos dos ensaios foram analisados por pelo teste de ANOVA seguida dos pós testes. Valores de probabilidade abaixo de $5 \%(p<0,05)$ foram considerados estatisticamente significantes. A análise foi realizada por meio do software GraphPad Prism versão 6 para Windows. 


\section{RESULTADOS}

\subsection{VIABILIDADE CELULAR}

Durante o cultivo celular para manutenção da linhagem e para preparação dos experimentos, as células foram contadas em câmara de Neubauer, previamente coradas com Trypan blue. A viabilidade das células recuperadas no cultivo foi superior a $90 \%$ durante todo o período de avaliação e experimentos descritos a seguir.

\subsection{ANÁLISE MORFOLÓGICA DA LINHAGEM TUMORAL CANINA}

Ao longo do cultivo celular a observação da morfologia sob microscopia óptica revelou um grupo celular que no início do cultivo se mostrou heterogêneo (células aderentes e não aderentes) com a presença de células esféricas, ovais e predomínio de células com aspecto estrelado, citoplasma amplo e espraiado, com crescimento e replicação moderados. Ao longo do cultivo celular, por volta da passagem 5, as células começaram a formar um predomínio de uma monocamada de células aderentes como pode ser observado na Figura 7.

Figura 7 - Fotomicrografia da linhagem tumoral em cultivo

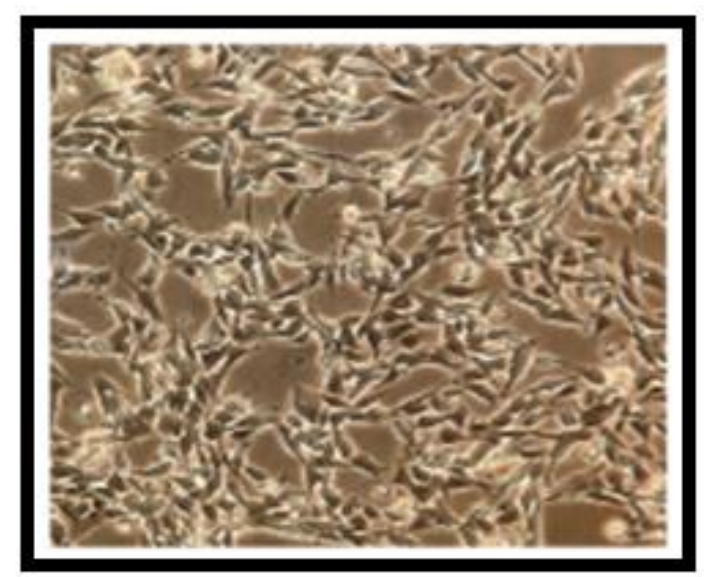

FONTE: SILVA, 2019.

Legenda: A morfologia das células cultivadas (denominada de MeLn) demonstra células que variam do formato fusiforme ao predomínio de células estreladas com citoplasma amplo e espraiadas (aumento 40x). 


\subsection{IMUNO-HISTOQUÍMICA}

Para caracterização e confirmação da obtenção de uma linhagem primária de melanoma canino metatático em nosso laboratório, as mesmas foram mantidas sob cultivo celular com repique (por tripsinização) a cada 3-4 dias e, na passagem 7, as mesmas foram submetidas a técnica de cell-block em agarose 2\% (Figura 8) para confirmação quanto a histogênese por meio do método de imuno-histoquímica.

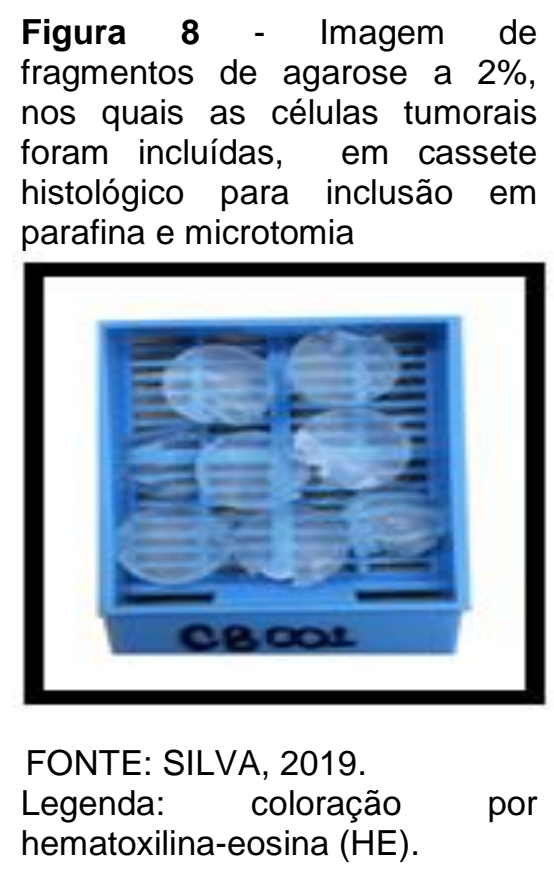

Sob a análise microscópica da lâmina histológica corada em HE, pode-se observar células dispostas em bloco, apresentando anisocitose, anisocariose, com núcleos paracentrais em eventuais células e alteração da relação núcleo/citoplasma (Figura 9). 
Figura 9 - Fotomicrografia de corte histológico de células de melanoma oral canino (MeLn) incluídas em agarose $2 \%$ (cell block)

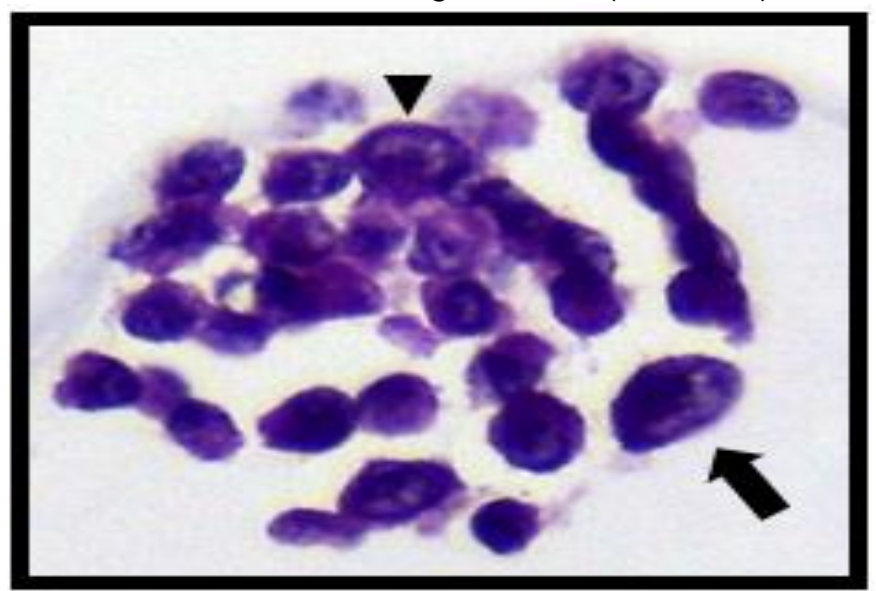

FONTE: SILVA, 2019.

Legenda: exibindo celularidade moderada, população celular esférica a elípticas, dispostas em bloco, apresentando anisocitose, anisocariose com núcleos paracentrais em eventuais células (seta) e alteração da relação núcleo/citoplasma (cabeça de seta). HE, 40x.

A análise imuno-histoquímica foi realizada para confirmar a histogênese das células tumorais. As figuras 6 e 7 ilustram a imunomarcação positiva para ambos os marcadores, confirmando a histogênese melanocítica da linhagem tumoral.
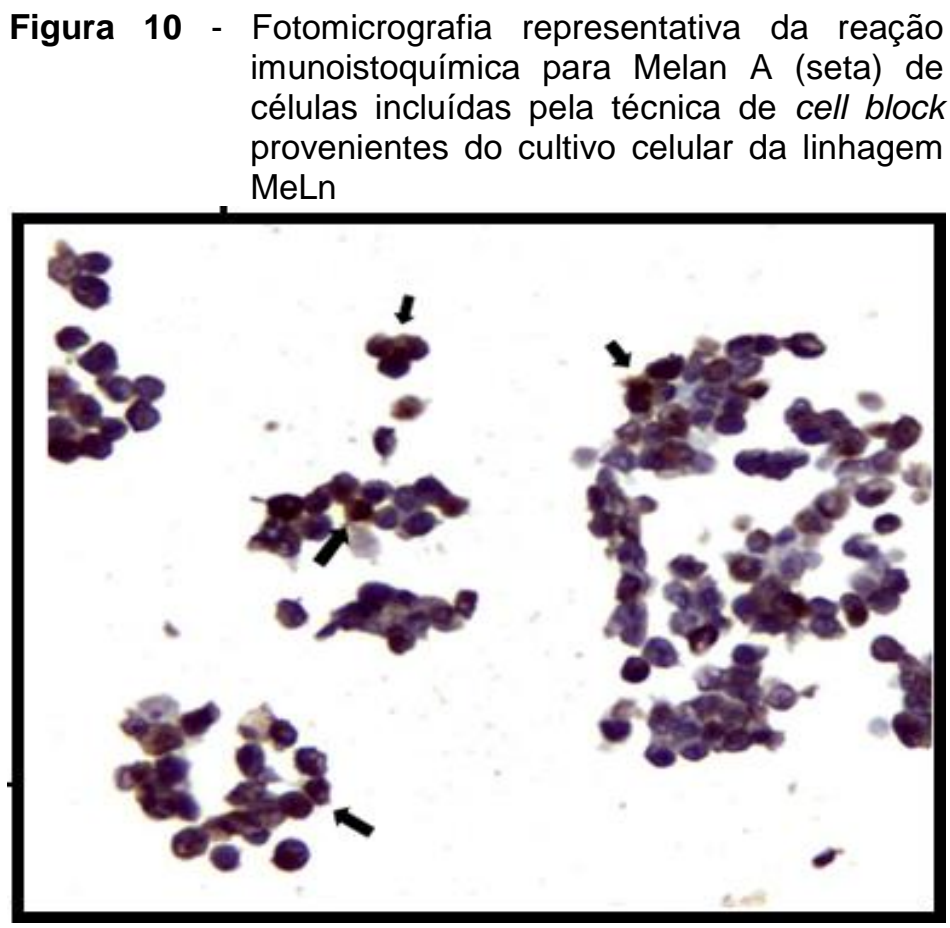

FONTE: SILVA, 2019.

Legenda: Marcação positiva corada em castanho escuro. Aumento de 40 vezes. 
Figura 11 - Fotomicrografia representativa da reação imunoistoquímica para PNL-2

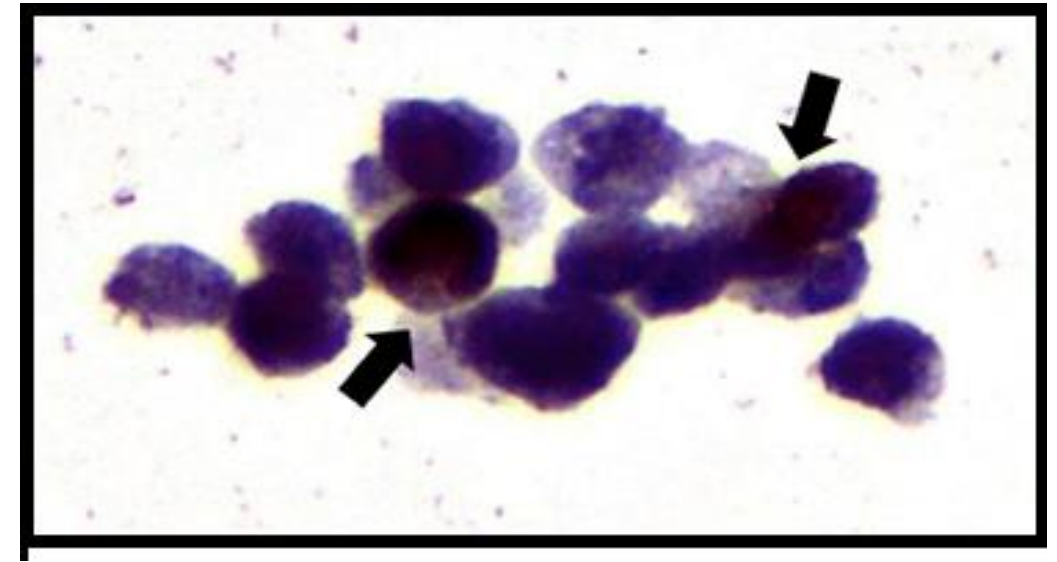

FONTE: SILVA, 2019.

Legenda: PNL-2 (seta) células incluídas pela técnica de cell block provenientes do cultivo celular da linhagem primária de linfonodo metastático de cão portador de melanoma oral.

\subsection{CICLO CELULAR DA LINHAGEM DE MELANOMA (MELN)}

A análise do ciclo celular da linhagem de melanoma canino derivado de linfonodo metastático (MeLn) foi realizada por marcação fluorescente do DNA pelo $\mathrm{PI}$, permitindo a determinação das fases do ciclo celular por citometria de fluxo (FACSCalibur). As análises por citometria de fluxo determinaram uma população celular homogênea tanto em tamanho quanto em complexicidade, demonstrado no citograma do tipo "dot plot". De forma resultante, a crescente parada do ciclo celular foi observada nas fases G1/G0, conforme apresentado na Figura 12D. 
Figura 12 - Efeitos da associação de diferentes concentrações da Doxorrubicina e Ivermectina no ciclo celular de uma linhagem de melanoma metastático canino (Meln)

A)

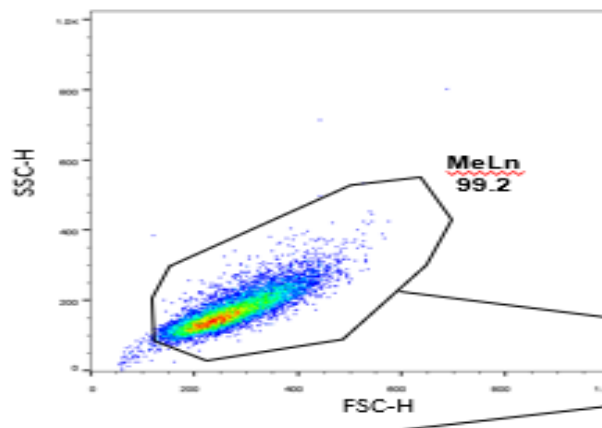

C)

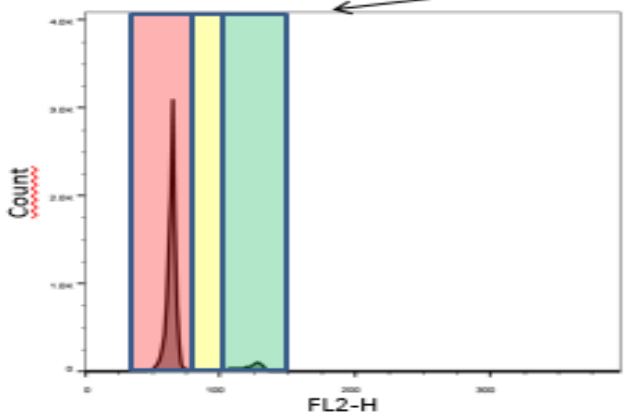

B)

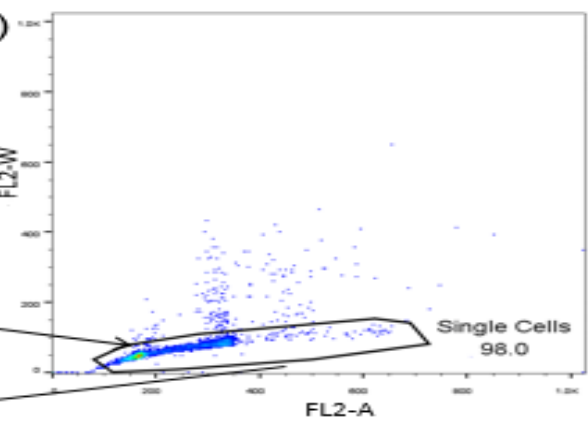

D)

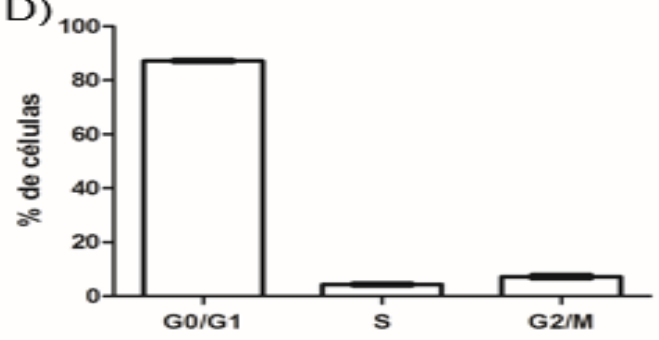

Legenda: A) citograma do tipo "dot plot" representativo, determinando a população mais homogênea em tamanho e complexidade interna e excluindo partículas muito pequenas (debris); B) Dot plot de fluorescência no canal FL2, com parâmetros FL2-A e FL2-W, os quais permitem a exclusão de grumos de células e análise somente de células individualizadas (single cells); C) Histograma representativo das células individualizadas, marcadas com PI, que determina a quantidade de DNA e fase do ciclo celular. Em vermelho: G0/G1, em amarelo: síntese, em verde: G2/ mitose; D) Quantificação do percentual de células em cada fase do ciclo. As colunas representam a média de 4 replicatas, e as barras o desvio padrão da média.

\subsection{TEMPO DE DUPLICAÇÃO}

Os tempos de duplicação calculados neste estudo baseiam-se no pressuposto de crescimento exponencial constante das células de melanoma na concentração de $0,5 \times 10^{6} / \mathrm{ml}$ ao decorrer dos tempos $0 \mathrm{~h}, 24 \mathrm{~h}, 48 \mathrm{~h}, 72 \mathrm{~h}$ e 96 horas. O tempo médio calculado para formação de uma nova geração celular foi de 30,45 horas como observado na figura 13. Já na concentração de 1,5x 106/ml o tempo de duplicação foi maior, cerca de 33,85 horas. Na figura 14, observa-se uma transição de um comportamento exponencial para um aumento no tempo de duplicação nos quais podem estar associadas a alterações no controle da replicação. Pode-se notar nas fotomicrografias das figuras 15 e 16, esse aumento progressivo da celularidade de acordo com o tempo e quanto a concentração de células. 
Figura 13 - Curva de crescimento celular na concentração de 0,5x 106/ml de acordo com o tempo

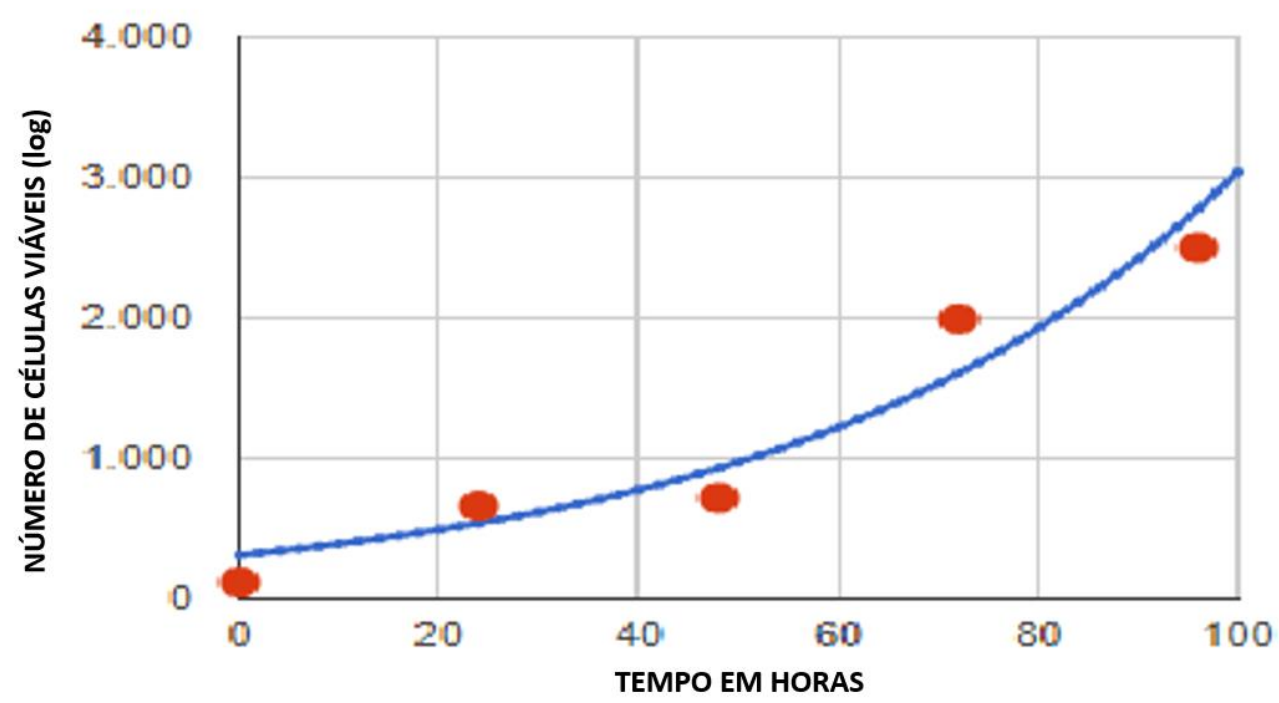

FONTE: SILVA, 2019.

Legenda: A curva demonstra que o tempo de duplicação foi de 30,45 horas e a taxa de crescimento celular (números de duplicações que ocorre por unidade de tempo) 0,0228 .

Figura 14 - Curva de crescimento celular na concentração de 1,5x 106/ml de acordo com o tempo

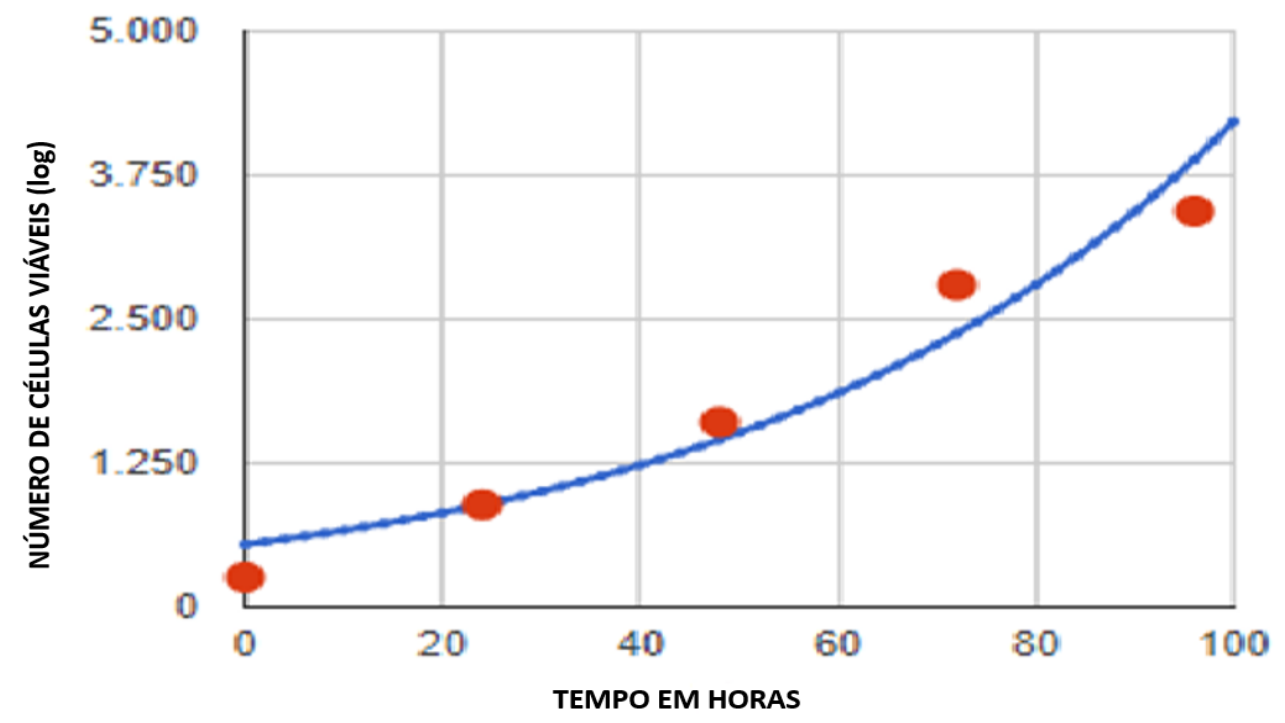

FONTE: SILVA, 2019.

Legenda: A curva demonstra que o tempo de duplicação foi de 33,85 horas e a taxa de crescimento celular (números de duplicações que ocorre por unidade de tempo) 0,0205 . 
Figura 15 - Fotomicrografias das células na concentração de $0,5 \times 10^{6}$ nos tempos de 0 a 96 horas

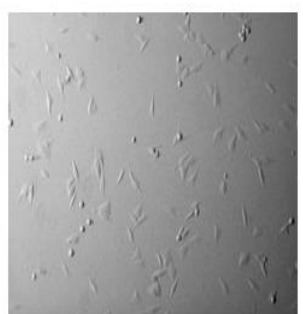

Ohoras

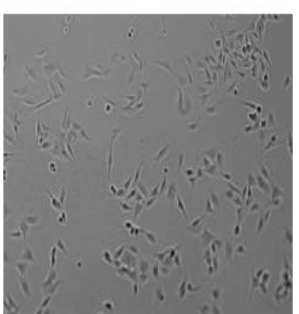

24 horas

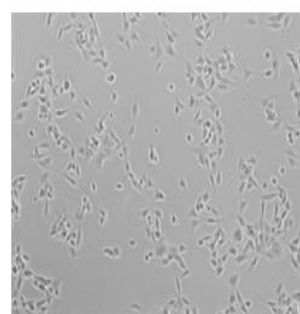

48 horas

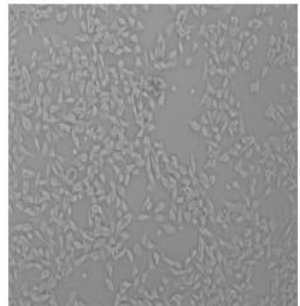

72 horas

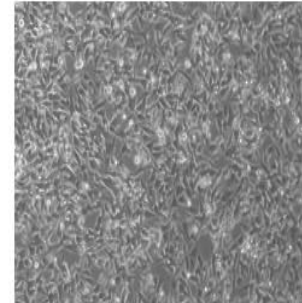

96 horas

FONTE: SILVA, 2019

Legenda: Aumento da confluência celular nas garrafas de acordo com o tempo, (aumento de 10x). $\mathrm{O}$ ensaio foi realizado em triplicata e as imagens correspondem a uma das triplicatas.

Figura 16 - Fotomicrografias das células na concentração de $1,5 \times 10^{6}$ nos tempos de 0 a 96 horas

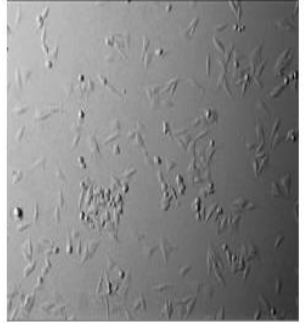

Ohoras

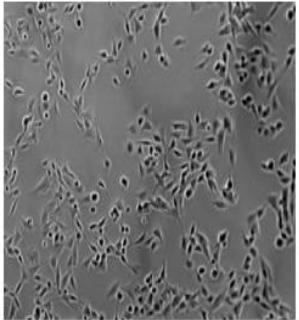

24 horas

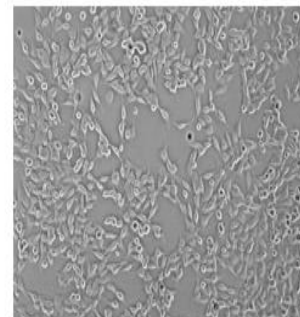

48 horas

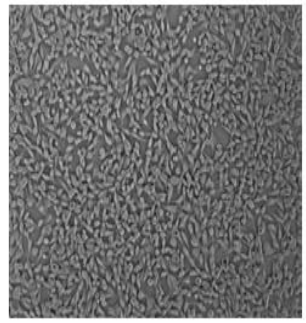

72 horas

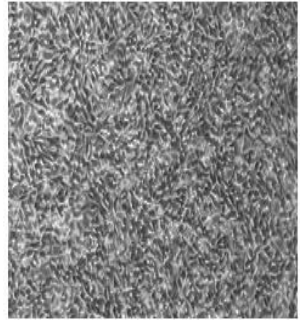

96 horas

FONTE: SILVA, 2019.

Legenda: Aumento da confluência celular nas garrafas de acordo com o tempo, (aumento de 10x). $\mathrm{O}$ ensaio foi realizado em triplicata e as imagens correspondem a uma das triplicatas.

\subsection{AVALIAÇÃO DA CITOTOXICIDADE PÓS TRATAMENTO}

Os resultados da avaliação de viabilidade das células no arranjo esferoide de melanoma canino após 48 horas de tratamento, estão expressos em porcentagem de morte celular. Os resultados obtidos na análise da viabilidade celular demonstrados na figura 17, apontam que os tratamentos com as associações de DX $0,5 \mu \mathrm{M}+\mathrm{IV}$ 1,5 mM (a) e DX 0,5 $\mathrm{mM}$ + IV 2,5 mM (B) exercem sua ação aumentando o percentual de morte celular quando comparado aos grupos controle ( $p<0,001$ ), DMSO ( $p<0,001)$, tratamento DX $(p<0,001)$ e também os três grupos de ivermectina nas três doses IV 0,5 mM ( $p<0,001)$, IV 1,5 Mm ( $p<0,001)$, IV 2,5 mM ( $p<0,001)$. Já o grupo $\mathrm{DX} \quad 0,5 \mu \mathrm{M}+\mathrm{IV} \quad 0,5 \mathrm{mM}$ apresentou diferença estatística significante quando comparado aos grupos das ivermectinas $(p<0,05)$. A DX exibe 
maior percentual de morte, apenas comparados aos grupos de ivermectina isolados, IV 0,5 mM ( $p<0,01)$, IV 1,5 Mm ( $p<0,001)$, IV 2,5 mM ( $<<0,001)$.

Figura 17 - Valores referentes a média \pm desvio da porcentagem da viabilidade das células no arranjo esferoides de uma linhagem de melanoma metastático canino expostas às diferentes concentrações de ivermectina e doxorrubicina e suas associações, assim como o respectivo controle e (DMSO) em cada placa de 24 poços

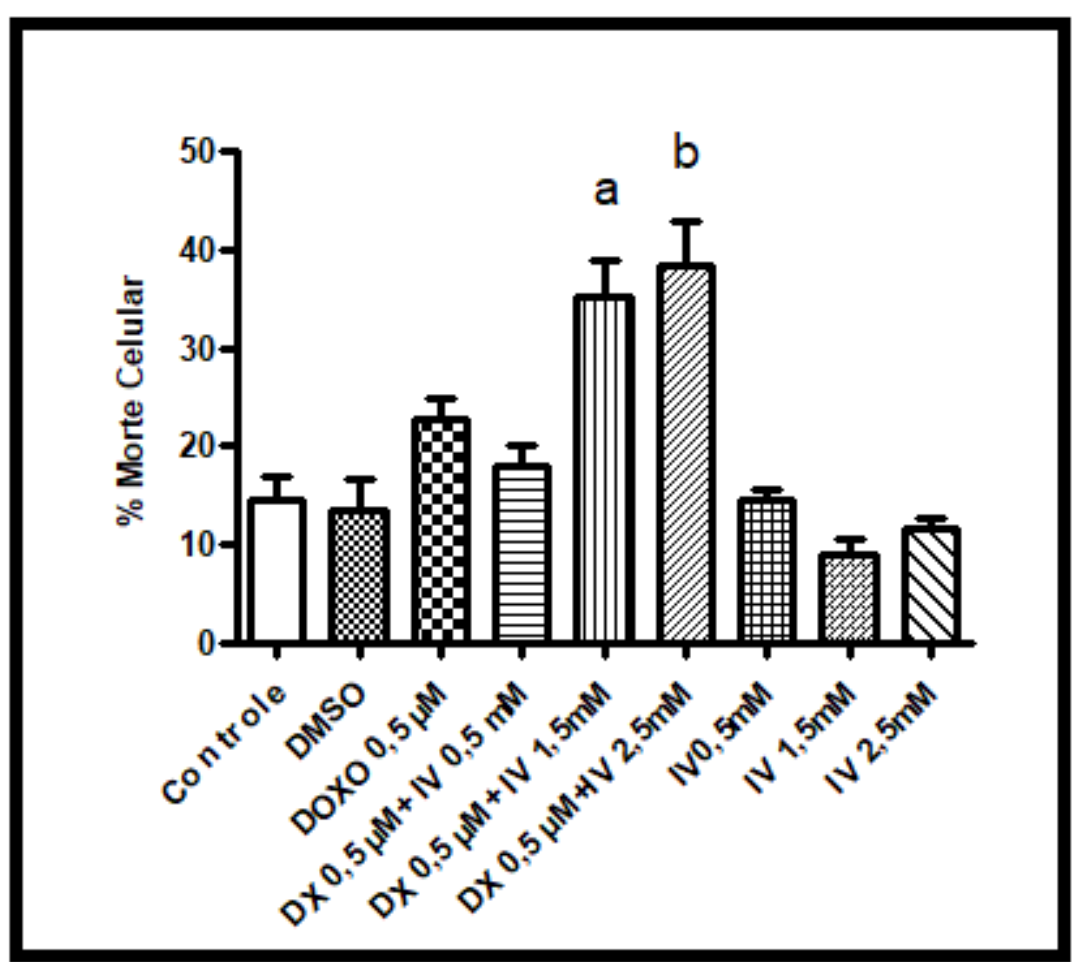

FONTE: SILVA, 2019.

Legenda: Letras $a, b(p<0,001)$, com relação aos grupos Controle, DMSO, DX, DX 0,5 $\mu \mathrm{M}+\mathrm{IV} 0,5 \mathrm{mM}$ IV 0,5 Mm, IV 1,5 Mm, IV 2,5 mM teste estatístico ANOVA de uma via seguido de pós teste de Tukey.

\subsection{AVALIAÇÃO DO PERFIL APOPTÓTICO E NECRÓTICO PÓS TRATAMENTO}

Os resultados da avaliação do perfil de células marcadas apenas com Anexina, representam morte celular por via de apoptótica, indicativo de apoptose inicial, células marcadas com duplo positivo para Anexina/ PI representam apoptose tardia, e apenas marcação por PI, indicativo de necrose celular após as 48 horas de tratamento Os valores estão expressos em porcentagem de morte celular. 
Tabela 2 - Valores referentes a média desvio padrão da porcentagem de células em apoptose inicial, apoptose tardia e necrose após 48 horas

\begin{tabular}{lccc}
\hline & $\begin{array}{c}\text { Apoptose Inicial } \\
\text { (\% células) }\end{array}$ & $\begin{array}{c}\text { Apoptose tardia } \\
\text { (\% células) }\end{array}$ & $\begin{array}{c}\text { Necrose } \\
\text { (\% células) }\end{array}$ \\
\hline DMSO & $2,72 \pm 0,04^{\mathrm{a}}$ & $1,50 \pm 0,56$ & $3,43 \pm 0,69$ \\
DX 0,5 $\mu \mathrm{M}$ & $1,14 \pm 0,15$ & $13,86 \pm 0,37^{\mathrm{a}}$ & $41,28 \pm 2,96^{\mathrm{a}}$ \\
DX 0,5 $\mu \mathrm{M}+\mathrm{IV} 0,5 \mathrm{mM}$ & $1,11 \pm 0,12$ & $16,28 \pm 1,89^{\mathrm{b}}$ & $42,00 \pm 11,61^{\mathrm{b}}$ \\
DX 0,5 $\mu \mathrm{M}+\mathrm{IV} 1,5 \mathrm{mM}$ & $1,12 \pm 0,43$ & $17,46 \pm 0,78^{\mathrm{c}}$ & $53,03 \pm 2,86^{\mathrm{c}}$ \\
DX 0,5 $\mu \mathrm{M}+\mathrm{IV} 2,5 \mathrm{mM}$ & $1,65 \pm 0,77$ & $21,05 \pm 3,21^{\mathrm{d}}$ & $56,85 \pm 4,58^{\mathrm{d}}$ \\
IV0,5mM & $3,38 \pm 0,42^{\mathrm{b}}$ & $2,32 \pm 1,15$ & $5,25 \pm 1,66$ \\
IV1,5mM & $3,81 \pm 0,07^{\mathrm{c}}$ & $4,52 \pm 0,71$ & $13,53 \pm 3,96$ \\
IV2,5mM & $3,77 \pm 0,23^{\mathrm{d}}$ & $3,06 \pm 0,68$ & $7,06 \pm 0,99$ \\
\hline
\end{tabular}

Legenda: Letras a, b , c, d representam os respectivos grupos que obtiveram diferença estatística quando comparado aos demais grupos. Teste estatístico ANOVA de uma via seguido do pós teste de Tukey.

Necrose: Como demonstrado na tabela 2, após o tempo de incubação de 48

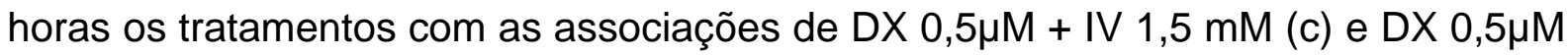
+ IV 2,5 mM (d), exercem sua ação aumentando o percentual de morte celular principalmente por via necrótica, quando comparado aos grupos, DMSO ( $p<$ $0,001), D X 0,5 \mu \mathrm{M}(p<0,01)$ e também os três grupos de ivermectina nas três doses IV 0,5 mM ( $p<0,001)$, IV 1,5 mM( $p<0,001)$, IV 2,5 mM $(p<0,001)$ e até mesmo a eficácia da maior dose, apresentou melhores resultados quando comparados ao grupo DX 0,5 $\mu \mathrm{M}+\mathrm{IV} 0,5 \mathrm{mM}(\mathrm{b})(\mathrm{p}<0,01)$.

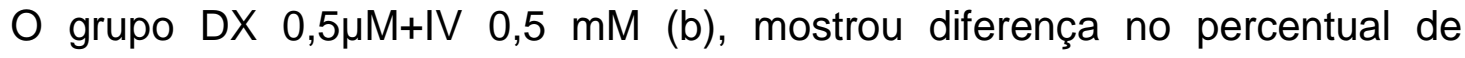
necrose quando comparado aos grupos, DMSO ( $p<0,001)$, IV 0,5 mM $(p<0,001)$, IV $1,5 \mathrm{mM}(p<0,001)$ e IV $2,5 \mathrm{mM}(\mathrm{p}<0,001)$.

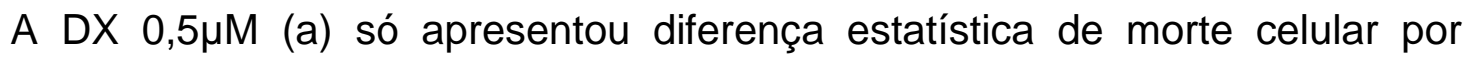
necrose em relação aos grupos: DMSO ( $p<0,001)$, IV 0,5 mM $(p<0,001)$, IV 1,5 $\mathrm{mM}(\mathrm{p}<0,001)$, IV 2,5 mM ( $p<0,001)$.

Apoptose inicial: Foi possível verificar que a apoptose inicial apresentou uma menor população de células marcadas nos grupos em geral, prevalecendo apenas o grupo DMSO(a), indicando diferença estatísticas em relação aos grupos DX $0,5 \mu \mathrm{M}$ $(p<0,001)$, DX 0,5 $\mu \mathrm{M}+\mathrm{IV} 0,5 \mathrm{mM}(\mathrm{p}<0,001), \mathrm{DX} 0,5 \mu \mathrm{M}+\mathrm{IV} 1,5 \mathrm{mM}(\mathrm{p}<0,001)$, $\mathrm{DX} 0,5 \mu \mathrm{M}+\mathrm{IV} 2,5 \mathrm{mM}(\mathrm{p}<0,01)$, e contra as ivermectinas IV $1,5 \mathrm{mM}(\mathrm{p}<0,01)$ e IV $2,5 \mathrm{mM}(\mathrm{p}<0,01)$. 
Os grupos das três concentrações de ivermectina apresentaram maior morte por apoptose do que a doxorrubicina isolada e todos os tratamentos associados, DX

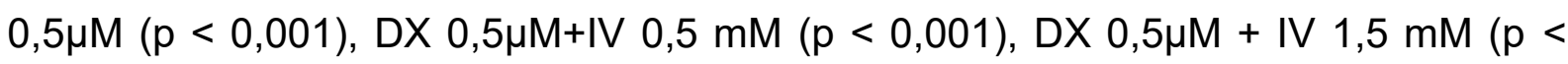

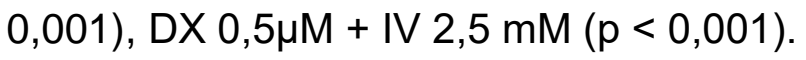

Apoptose final : Os resultados do porcentual de células em estágio de apoptose final, marcadas por anexina/PI, seguem o mesmo perfil de diferença estatística intragrupos que as células marcadas por via necrótica, onde as

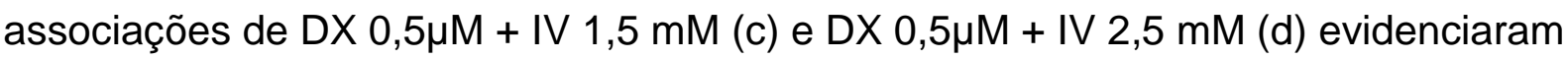
um aumento do percentual de morte celular por apoptose tardia, quando comparado

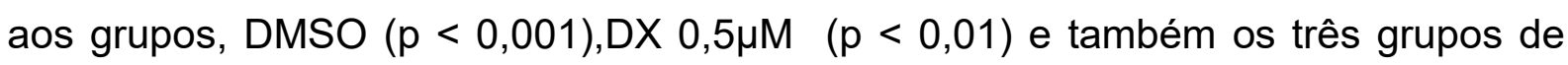
ivermectina nas três doses IV 0,5 mM ( $p<0,001)$, IV 1,5 mM(p<0,001), IV 2,5 mM ( $p<0,001)$ e até mesmo a eficácia da maior concentração, apresentou maior

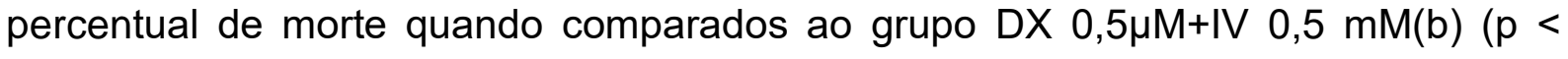

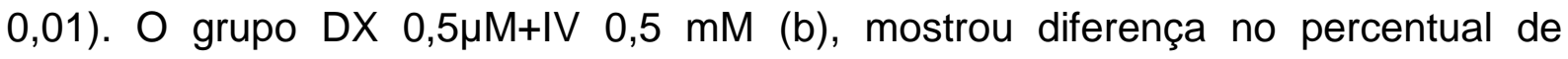
apoptose tardia quando comparado aos grupos, DMSO ( $p<0,001$ ), IV 0,5 mM (p $<0,001)$, IV 1,5 mM ( $<<0,001)$ e IV 2,5 mM ( $<<0,001)$. A Doxorrubicina isolada, DX $0,5 \mu \mathrm{M}$ (a) apresentou diferença estatística significante de morte celular por necrose em relação aos grupos: DMSO ( $p<0,001)$, IV 0,5 mM ( $p<0,001)$, IV 1,5 mM(p< $0,001)$, IV $2,5 \mathrm{mM}(\mathrm{p}<0,001)$

\subsection{AVALIAÇÃO DA MIGRAÇÃO CELULAR- MÉTODO WOUND HEALING}

As células realizam o processo de migração celular no organismo tanto em condições fisiológicas na qual desempenham diversas funções como reparo de regiões lesionadas, diferenciação celular, mas também em condições patológicas no caso de um processo metastático. Para análise do perfil de migração celular das células de melanoma canino (MeLn), foi realizado o ensaio de wound healing com as células em monocamada. 
Figura 18 - Efeito dos diferentes tipos de tratamento na migração células tumorais de melanoma canino metastático, avaliados nos tempos 0hrs, $24 \mathrm{hrs}$ e $48 \mathrm{hrs}$. $\mathrm{O}$ ensaio foi feito em triplicata e as imagens correspondem a umas das triplicatas
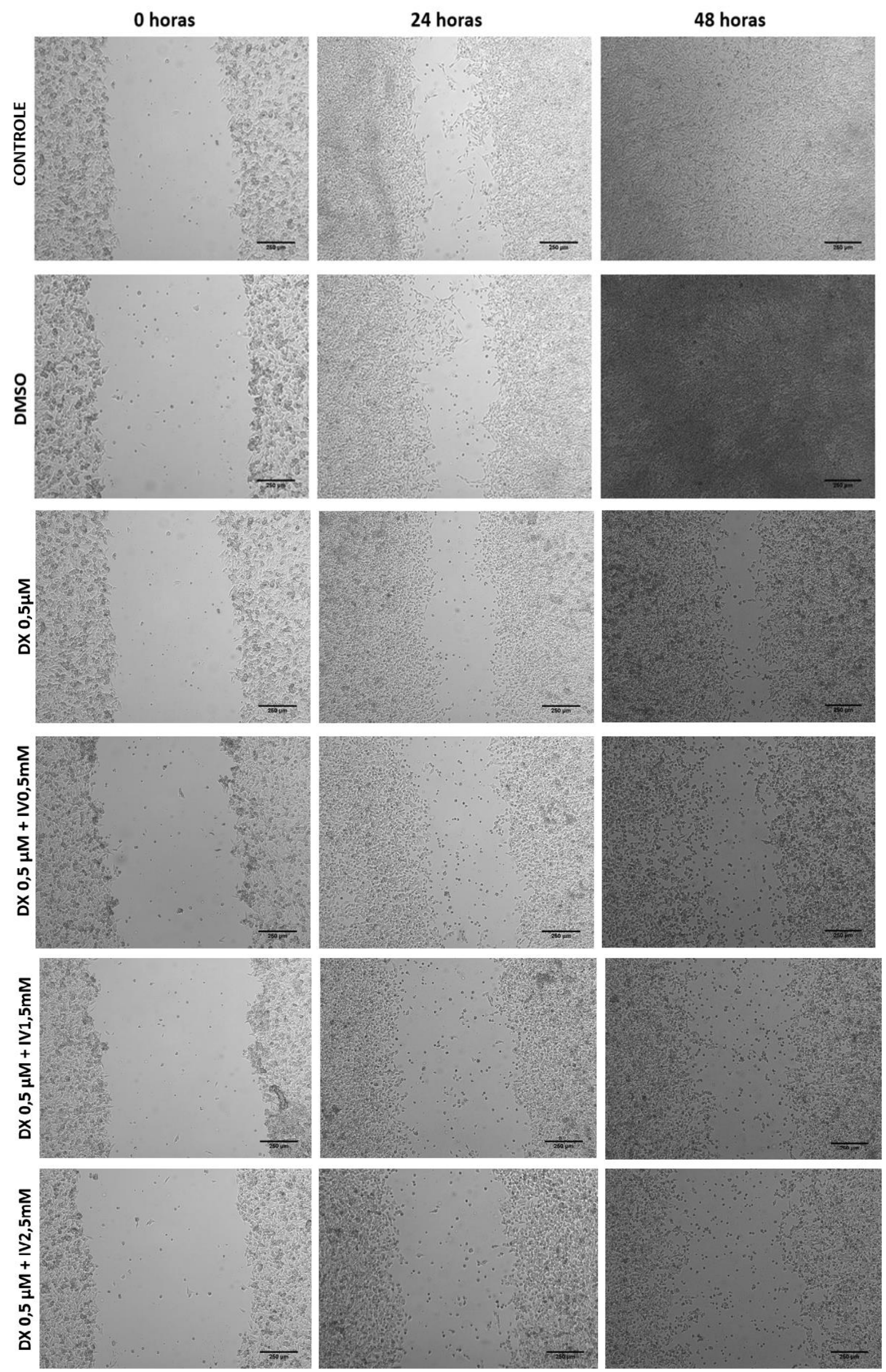

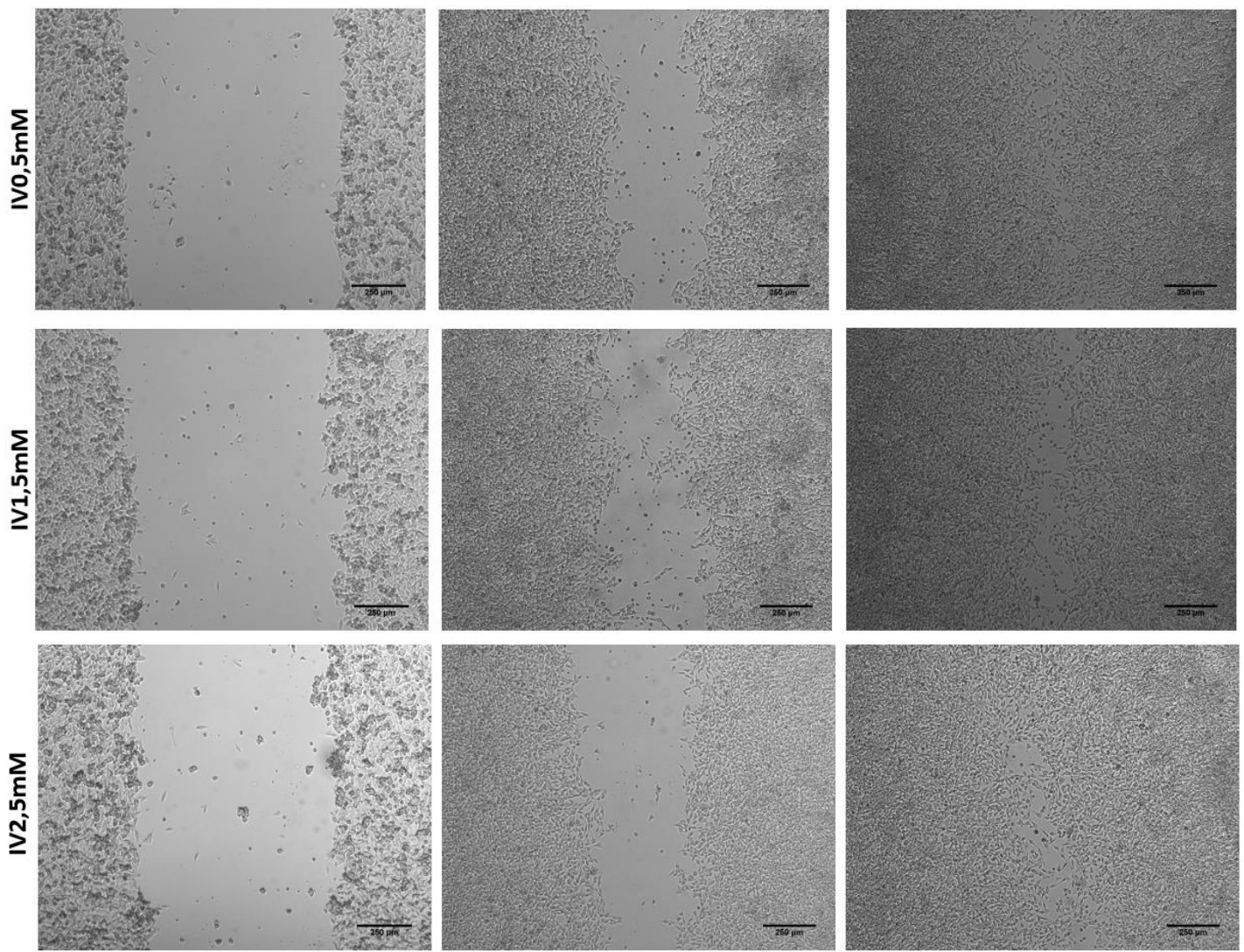

FONTE: SILVA, 2019.

Figura 19 - Efeito dos diferentes tipos de tratamentos na migração das células tumorais de melanoma canino metastático. O ensaio foi realizado em triplicata

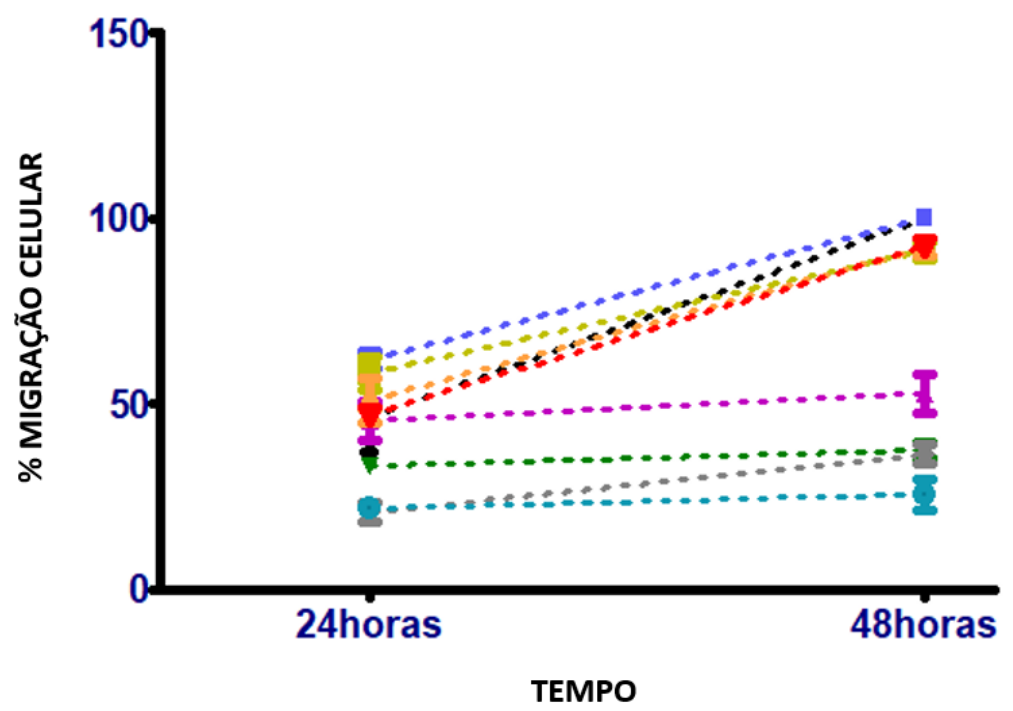

- CONTROLE

- DMSO

$\leftarrow \mathrm{DX} 0,5 \mu \mathrm{M}$

* DX 0,5 $\mu \mathrm{M}+\mathrm{IV} 0,5 \mathrm{mM}$

$\rightarrow D X 0,5 \mu \mathrm{M}+\mathrm{IV} 1,5 \mathrm{mM}$

- DX $0,5 \mu \mathrm{M}+\mathrm{IV} 2,5 \mathrm{mM}$

들 $\mathrm{IV} 0,5 \mathrm{mM}$

는 $\mathrm{IV}, 5 \mathrm{mM}$

- IV $2,5 \mathrm{mM}$

FONTE: SILVA, 2019.

Legenda: Porcentagem de fechamento das células entre as 24 horas e 48 horas. $O$ ensaio foi realizado em triplicata e os valores referentes a média \pm desvio padrão dos grupos, ${ }^{*} p<0.05$, teste estatístico ANOVA de uma via, seguido do pós teste de Tukey. 
Figura 20 - Efeito dos diferentes tipos de tratamentos na migração das células tumorais de melanoma canino metastático. O ensaio foi realizado em triplicata

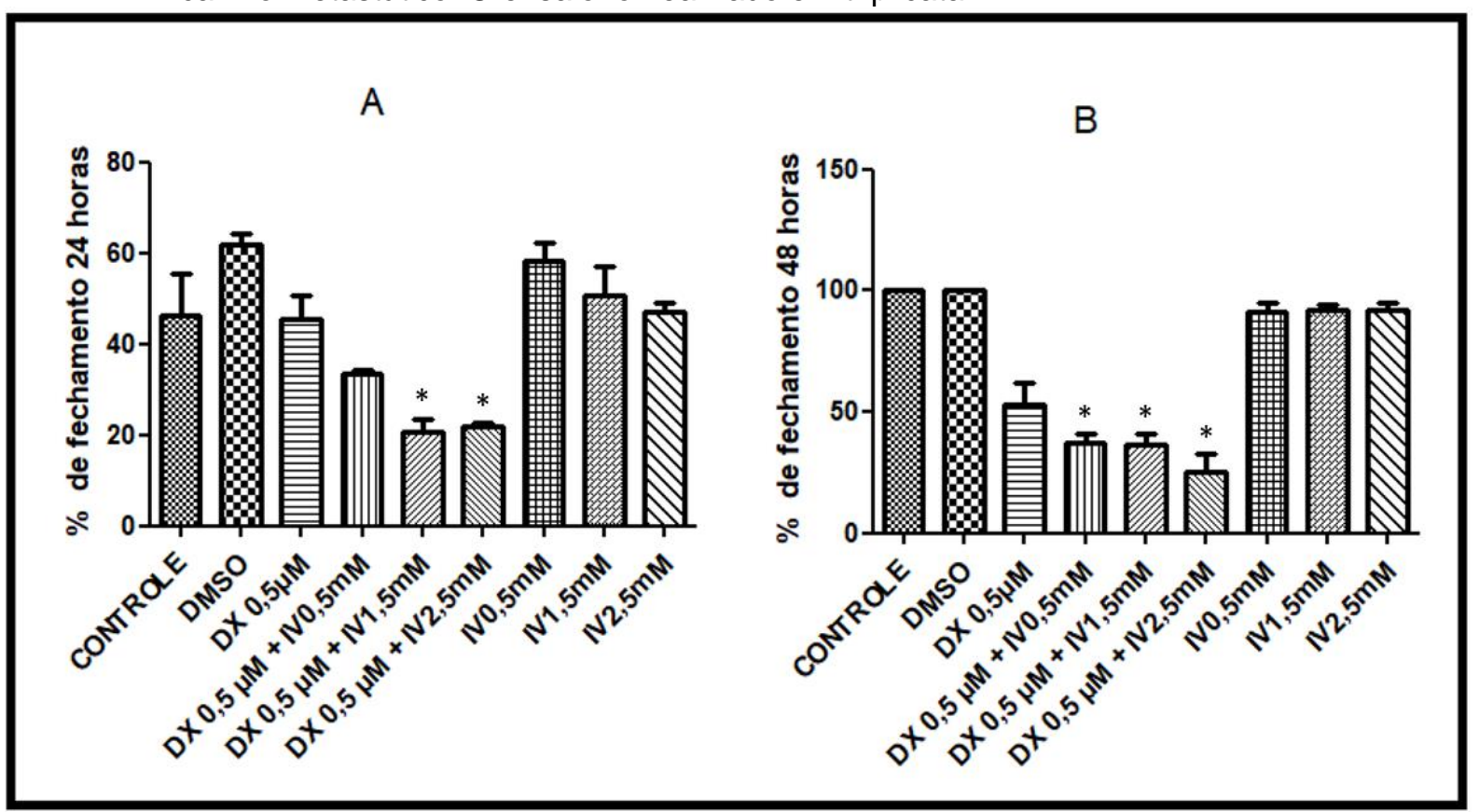

FONTE: SILVA, 2019.

Legenda: Porcentagem de fechamento das células de acordo com os tempos, (A) 24horas e (B) 48 horas. Valores referentes a média \pm desvio padrão dos grupos, ${ }^{*} p<0.05$, teste estatístico ANOVA de uma via, seguido de pós teste de Tukey.

A Figura 20 e o Gráfico A permitem observar que após o tempo de incubação de 24 horas os tratamentos com as associações de DX 0,5 $\mu \mathrm{M}+\mathrm{IV} 1,5 \mathrm{mM}$ e DX $0,5 \mu \mathrm{M}+$ IV 2,5 mM exercem sua ação diminuindo o percentual de migração celular quando comparado ao grupo Controle $(p<0,05)$, DMSO $(p<0,001)$, tratamento DX $(p<0,05)$ e também os três grupos de ivermectina nas três doses IV 0,5 mM ( $p$ $<0,001)$, IV 1,5 mM ( $p<0,01)$, IV 2,5 mM ( $p<0,05)$. Já o grupo DX 0,5 $\mu M+$ IV 0,5 $\mathrm{mM}$ apresentou diferença estatística significante na diminuição da migração celular quando comparado ao grupo IV 0,5 mM $(p<0,05)$.

Após as 48 horas é possível observar no gráfico $B$ da figura 20, que os grupos Controle, DMSO e IV 0,5 mM, IV 1,5 mM, IV 2,5 apresentam um padrão de fechamento completo da fissura, evidenciando o perfil atóxico da ivermectina e o veículo sobre as células de melanoma. Diferentemente dos tratamentos como a DX $0,5 \mu \mathrm{M}$ isolada, comprovando seu efeito citotóxico sobre as células, a mesma apresenta diferença estatística em relação aos grupos Controle e DMSO $(p<0,001)$, e os três grupos de ivermectina nas três doses IV 0,5 mM, IV 1,5 mM, IV 2,5 mM ( $p$ $<0,001$ ), assim como também demonstrou efeito sobre a inibição do fechamento da ferida $\mathrm{DX} 0,5 \mu \mathrm{M}+\mathrm{IV} 0,5 \mathrm{mM}(\mathrm{p}<0,05)$. 
Os resultados observados na figura B de 48 horas da exposição aos

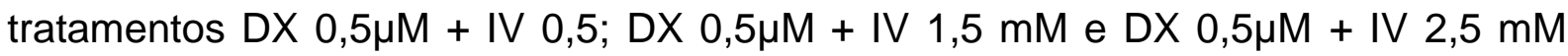
foram capazes de inibir a migração celular e apresentam diferença estatística em relação aos grupos Controle e DMSO ( $p<0,001)$, e os três grupos de ivermectina nas três doses IV 0,5 mM, IV 1,5 mM, IV 2,5 mM ( $p<0,001)$. Como efeito sinérgico,

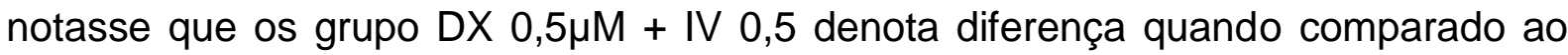
grupos $\mathrm{DX} 0,5 \mu \mathrm{M}$ isolada $(\mathrm{p}<0,05)$, sendo o efeito progressivo quando comparado

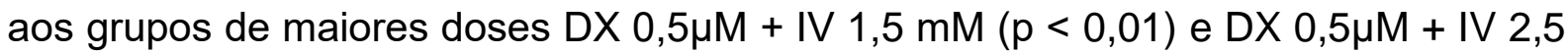
$\mathrm{mM}(\mathrm{p}<0,001)$.

Os dados estatísticos reportados acima, podem ser notados visivelmente na figura 18 onde as imagens dos grupos Controle e DMSO apresentam um fechamento completo da linha central após as 48 horas, evidenciando uma progressão da migração e crescimento celular. Aparentemente os grupos IV 0,5 mM, IV 1,5 mM, IV 2,5 mM, apresentam um fechamento acentuado da falha ao longo do tempo, permanecendo apenas com pequenos sulcos durante a fissura, representando uma baixa tendência de toxidade da Ivermectina.

Com relação aos resultados apresentados pelo grupo DX 0,5 $\mu \mathrm{M}$, a fotomicrografia apresenta um fechamento menor ao final das 48 horas com a presença de células arredondadas e suspensas no meio por perda de aderência, caracterizando morte celular, como efeito esperado do fármaco. E como demostrado na análise estatística, os grupos com as associações, DX $0,5 \mu \mathrm{M}+\mathrm{IV} 0,5 ; \mathrm{DX}$ $0,5 \mu \mathrm{M}+\mathrm{IV} 1,5 \mathrm{mM}$ e DX 0,5 $\mathrm{M}$ + IV 2,5 mM, evidenciam um menor fechamento da fissura na garrafa, quando comparado aos demais grupos, onde, quanto maior a dose da IV consequentemente menor a migração das células, e maior o desprendimento das células da garrafa e maior número de morte celular. 


\subsection{AVALIAÇÃO DO CICLO CELULAR}

Figura 21 - Gráfico representativo da análise de ciclo celular pós tratamentos avaliado pela técnica de citometria de fluxo

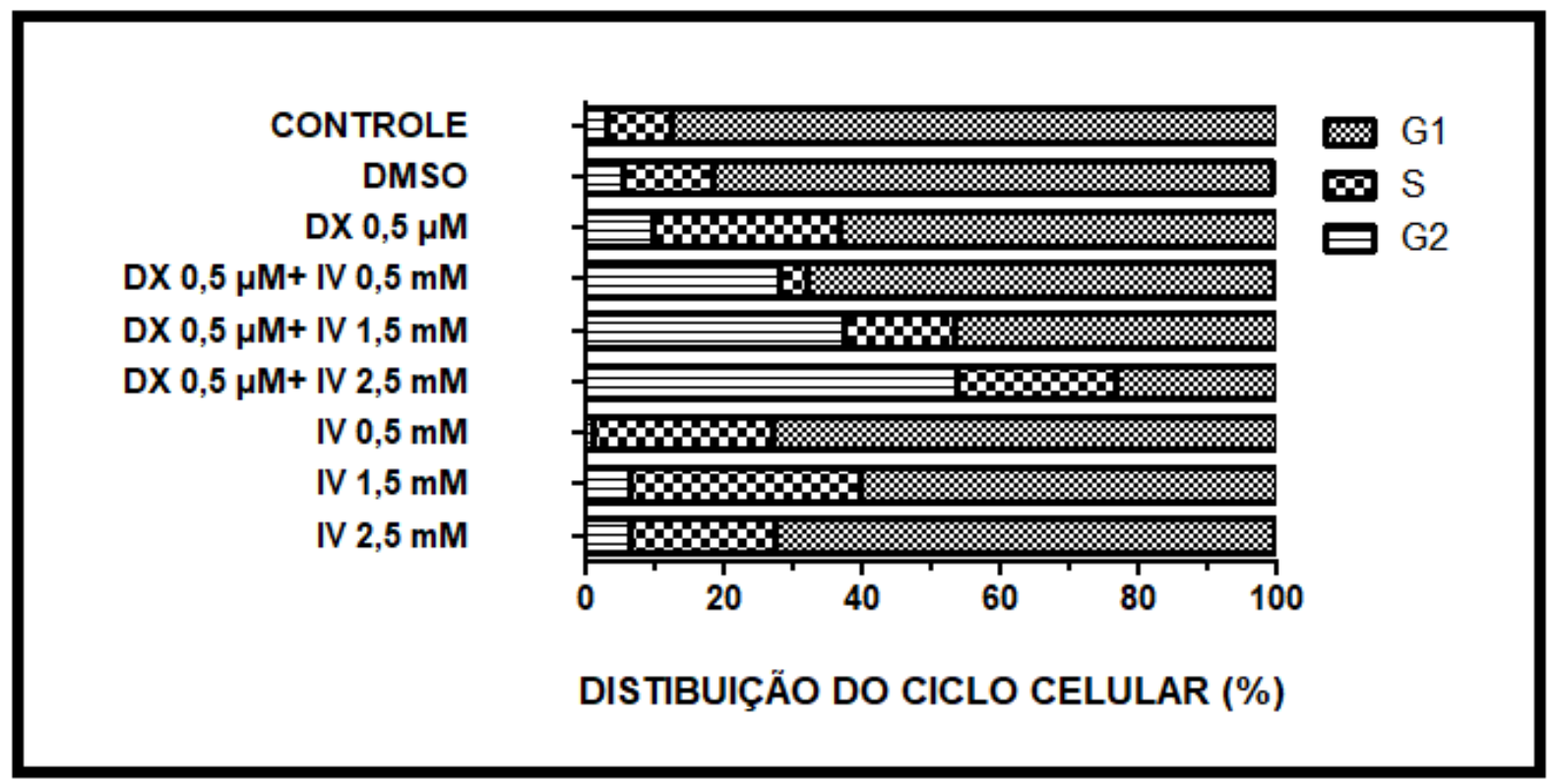

FONTE: SILVA, 2019.

Legenda: Valores referentes a média, onde as colunas representam a média de duas triplicatas; teste estatístico ANOVA de uma via, seguido de pós teste de Tukey.

A figura 21 ilustra os resultados referentes ao ciclo celular e como as fases se distribuem frente aos diferentes tipos de tratamento após as 48 horas. Os resultados estão expressos em porcentagem de distribuição do ciclo celular. A análise aponta que os grupos Controle e DMSO exercem uma parada do ciclo celular observada na

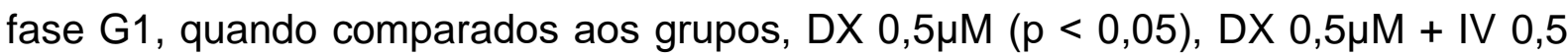
$\mathrm{mM}(\mathrm{p}<0,05), \mathrm{DX} 0,5 \mu \mathrm{M}+\mathrm{IV} 1,5 \mathrm{mM}(\mathrm{p}<0,01) ; \mathrm{DX} 0,5 \mu \mathrm{M}+\mathrm{IV} 2,5 \mathrm{mM}(\mathrm{p}<0,001)$, IV $1,5 \mathrm{Mm}(p<0,05)$; não houve diferença estatística significante quando comparado aos grupos, IV 0,5 mM, e IV 2,5 mM. Os grupos IV 0,5 mM, IV 2,5 mM apresentaram maior percentual de parada do ciclo celular na fase G1 quando comparado aos grupos IV $0,5 \mu \mathrm{M}+\mathrm{IV} 1,5 \mathrm{mM}(\mathrm{p}<0,01) ; \mathrm{DX} 0,5 \mu \mathrm{M}+\mathrm{IV} 2,5 \mathrm{mM}(\mathrm{p}<0,001)$. Ainda na fase G1 o grupo IV $1,5 \mathrm{mM}$ também apresentou diferença estatisticamente

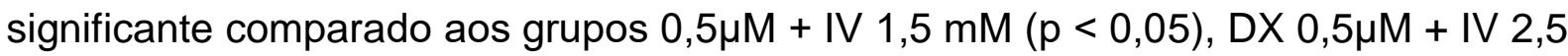
$\mathrm{mM}(\mathrm{p}<0,01)$.

Quanto a fase $S$ do ciclo celular, apresentou-se sem diferença estatística significantes entre a maioria dos grupos, permanecendo apenas um grupo $\mathrm{DX} 0,5 \mu \mathrm{M}$ 
+ IV 0,5 mM $(p<0,01)$ com menor percentual de fase $S$ quando comparado a todos os outros tratamentos, controle e veículo.

A fase G2 mostrou-se progressiva quando observada nas associações de ivermectina e doxorrubicina, os tratamentos com as associações de DX 0,5 $\mathrm{M}+\mathrm{IV}$

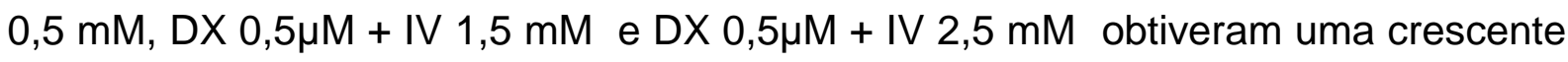
parada em G2 quando comparado aos grupos Controle ( $p<0,001)$, DMSO ( $p<$ $0,001)$, tratamento $\mathrm{DX}(\mathrm{p}<0,001)$ e também os três grupos de ivermectina nas três doses IV 0,5 mM ( $p<0,001)$, IV 1,5 Mm ( $p<0,001)$, IV 2,5 mM ( $p<0,001)$.

Ainda assim, o grupo DX 0,5 $\mathrm{MM}$ + IV 2,5 mM obteve diferença estatística significante com uma maior porcentagem de células na fase G2 em comparação ao

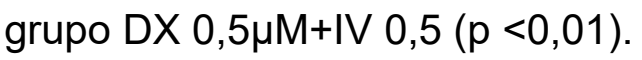

Já o grupo DX $0,5 \mu \mathrm{M}$ apresentou diferença estatística significante quando comparado ao grupo IV 0,5 mM, $(p<0,05)$. 


\section{DISCUSSÃO}

Apesar dos avanços farmacológicos contra diversos tipos de câncer, a resistência a múltiplas drogas (MDR) continua sendo um grande obstáculo para alcançar resultados terapêuticos positivos, tanto na medicina humana como veterinária(NANAYAKKARA et al., 2018; ONG et al., 2017). Estima-se que a resistência aos quimioterápicos cause falha no tratamento em mais de $90 \%$ dos pacientes com câncer metastático (HAYES; WOLF, 1990).

Levando em consideração esses dados, o melanoma metastático é um tumor altamente resistente a rádio e quimioterapias convencionais, onde o paciente apresenta uma baixa sobrevida após diagnóstico (LEFRANC; MATHIEU; KISS, 2011; MATHIEU et al., 2012). Já existe um prévio conhecimento que a glicoproteínap em melanoma humano como canino, correlaciona-se positivamente com a progressão neoplásica, sugerindo que a expressão de Gp-p está associada à agressividade do tumor e a capacidade de expulsão dos fármacos(CHARTRAIN et al., 2012; FINOTELLO et al., 2017).

Dada a importância do fenômeno de resistência aos quimioterápicos procuramos reunir resultados de vários estudos centrados na compreensão desse mecanismo, e no estabelecimento das relações dos efeitos da Ivermectina que vem se mostrando como um agente modulador da resistência das células tumorais, e visando sua associação com a Doxorrubicina, um fármaco quimioterápico que sofre expulsão pela Gp-p (POULIOT et al., 1997).

De inicial, foi necessário realizar a confirmação e caracterização da linhagem celular primária de melanoma canino (MeLn) extraída de um linfonodo de cão, pois a mesma não foi obtida de um banco de células com as devidas caracterizações.

Para caracterização e confirmação da linhagem, analisamos a viabilidade das células recuperadas no cultivo, onde mostrou-se superior a $90 \%$ durante todo o período de avaliação e experimentos. Neste estudo foi constatado que essa linhagem se apresentava no início do cultivo sob uma forma heterogênea com a presença de células aderentes e não aderentes esféricas. As células aderentes apresentavam um aspecto estrelado, com o citoplasma amplo e espraiado e de crescimento e replicação moderados, e aspecto estrelado.

Sabe-se que o melanoma expressa proteínas de matriz extracelular que contribuem para o desenvolvimento de alterações celulares, levando a um padrão 
histológico e imunoistoquimico diferenciado quando comparado a células normais (RAMOS-VARA; MILLER, 2011). Dessa forma foram utilizados marcadores comumente empregados na clínica veterinária para confirmação da linhagem de melanoma, o anti-MelanA e anti-PNL2, cujo resultado mostrou-se positivo para ambos os marcadores, confirmando a histogênese melanocítica da linhagem tumoral (RAMOS-VARA; MILLER, 2011).

A determinação do tempo de duplicação da linhagem Meln em cultura é um passo importante para realização dos estudos envolvendo o efeito da associação farmacológica, auxiliando a compreender melhor a viabilidade celular, pois permite determinar com precisão o momento em que a cultura atingirá a confluência adequada no cultivo (VILELA et al., 2005).

Assim, foi analisado o tempo de duplicação das células de melanoma canino (Meln) na concentração de $0,5 \times 10^{6} / \mathrm{ml}$ onde apresentou-se com o tempo de aproximadamente 30,34 horas e na concentração de 1,5 x 106/ml foi de 33,85 horas.

Pode-se notar uma variação do tempo de replicação entre as duas concentrações, sendo que, na maior concentração o tempo de duplicação aumentou, essa variação pode ter ocorrido devido alterações nos padrões de expressão de moléculas relacionadas com sinalização intracelular, essa resposta adaptativa é gerada devido a mecanismos de restrições ao crescimento impostas por uma elevada densidade populacional ou por uma longa permanência em cultura (HANAHAN \& WEINBERG, 2000).

O tempo de duplicação de ambas as concentrações expõe uma característica de células tumorais onde se espera uma alta capacidade de se duplicarem rapidamente. De acordo com a Thawing, Propagating and Cryopreserving Protocol (ATCC) 2013 células de melanoma humano (SK-Mel-30), mostram que o tempo de duplicação dessa linhagem em uma concentração 6,0 × $10^{6}$ é de aproximadamente 30 horas. Apesar de linhagens distintas e modelos diferentes, podemos notar que em nossa caracterização, as células MeLn em uma concentração menor teve um grande potencial de duplicação.

Esse aumento de duplicação observado nessa linhagem pode ter origem do aumento da atividade e/ou expressão de telomerase, enzima que reconstrói estas estruturas, possibilitando um número virtualmente infinito de divisões celulares, num processo chamado imortalização celular (MEYERSON, 2000).

Dessa forma, concluímos que as evidências apresentadas nesse estudo 
sobre a linhagem primária extraída de um linfonodo de cão, tem como caracterização de uma célula de melanoma canino e a mesma apresenta capacidade de se duplicar de forma a manter-se em cultivo para dar continuidade ao projeto com o uso da associação de Ivermectina e Doxorrubicina.

Nesse estudo também procurou-se avaliar o ciclo celular da linhagem metastática, a fim de compreender melhor os mecanismos de duplicação. Sabe-se que o processo de proliferação celular é extremamente coordenado onde cada fase do ciclo celular é regulado por uma rede bioquímica complexa, que sinaliza o andamento e as passagens entre G1, S, G2 e M (MALUMBRES; BARBACID, 2009).

Um dos genes ligados a essa regularização do ciclo celular é o p16INK4a, sendo o mesmo responsável por codificar proteínas inibidoras do ciclo celular, e encontra-se frequentemente alterado em vários tipos de tumores, é constatado uma susceptibilidade desse gene para o melanoma, pois o mesmo promove as funções inibitórias de crescimento do retinoblastoma $(\mathrm{Rb})$. Em melanomas esporádicos, várias alterações do p16INK4a têm sido observadas. Sabe-se que a divisão célular é regulado por uma família de proteinoquinases conhecidas como quinases ciclinodependentes (CDKs)(KELLER-MELCHIOR; SCHMIDT; PIEPKORN, 1998).

A ativação sequencial de membros individuais dessa família e suas consequentes fosforilações de substratos críticos promovem progressão ordenada pelo ciclo celular. Os complexos formados pela CDK4 e o tipo D de ciclinas estão fortemente implicados no controle da progressão celular, durante a fase G1. Como esperado, alterações do p16INK4a resulta na parada do ciclo celular em G1 por inibição da fosforilação da proteína $\mathrm{Rb}(\mathrm{pRb})$ pelas quinases ciclino-dependentes CDK4 e CDK6 (KELLER-MELCHIOR; SCHMIDT; PIEPKORN, 1998).

Como sugestão, a crescente parada do ciclo celular na fase $\mathrm{G} 1$, conforme o resultado apresentado em nossa linhagem de melanoma tumoral, pode ter origem de alterações no gene p16INK4a (KELLER-MELCHIOR; SCHMIDT; PIEPKORN, 1998).

Os resultados obtidos de citotoxicidade com os tratamentos das células esferoides de melanoma canino metastático, com a associação de Doxorrubicina e Ivermectina, corroboram os achados de Furusawa et. al (2000) onde, as associações nas doses, Doxorrubicina 0,5 $\mu \mathrm{M}$ + Ivermectina 1,5 mM e Doxorrubicina $0,5 \mu \mathrm{M}+$ Ivermectina $2,5 \mathrm{mM}$ foram capazes de aumentar de maneira significante 0 
percentual de morte celular, com diferença estatística significante, quando comparada a todos os tratamentos e controle.

No estudo de Furusawa et. al, 2000, é demonstrado o mesmo comportamento de morte celular da linhagem P388 de células de leucemia resistentes a Doxorrubicina, quando os fármacos estão associados, quando testada a concentração de $2 \mu \mathrm{M}$ de Ivermectina $+1 \mu \mathrm{M}$ de Doxorrubicina. Umas das possíveis explicações para interpretar esse perfil, se dá pelo aumento da sensibilidade celular à doxorrubicina, quando a mesma é associada a Ivermectina. Sugeriu-se que a ivermectina reverte a resistência por interação direta com a glicoproteína $P$ e outros componentes da membrana celular uma vez que este estudo demonstrou por meio de uma sonda fluorescente, 3,3 dihexil-oxacarbocyanine que a ivermectina foi capaz de induzir um aumento do potencial de membrana plasmática em células resistentes a doxorrubicina, permitindo assim que a doxorrubicina permeie para dentro das células.

Demonstramos que o efeito da associação farmacológica, na metade da dose de Doxorrubicina comparada ao estudo de Furasawa et. al, 2000, foi capaz de aumentar o percentual de morte celular em cerca de $15 \%$ a mais do que a Doxorrubicina isolada, esse dado foi obtido quando comparado ao grupo Doxorrubicina $0,5 \mu \mathrm{M}+$ Ivermectina $2,5 \mathrm{mM}$.

Após análise de citotoxidade, foi necessário verificar por qual via essa associação estaria levando a morte das células, sabendo-se que o efeito da Doxorrubicina tem como principal manifestação, alterações nas características morfológicas associadas à apoptose.

Em nossos achados, apesar da porcentagem de células apresentarem um percentual de morte celular por apoptose tardia, evidenciado principalmente nos grupos das associações da Doxorrubicina $0,5 \mu \mathrm{M}+$ Ivermectina $1,5 \mathrm{mM} \mathrm{e}$ Doxorrubicina $0,5 \mu \mathrm{M}$ + Ivermectina $2,5 \mathrm{mM}$, ainda sim quando comparamos os três tipos de manifestações celular gerado pelo mecanismo de ação das associações, percebemos que a diferença estatística significante de morte celular, foi maior pela via de necrose, ou seja a associação aumentou o percentual de morte celular por necrose.

Apesar do mecanismo de morte descrito para a Doxorrubicina ser por via apoptótica, os resultados indicam que as células tratadas com este quimioterápico morreram via apoptose tardia e necrose (FURUSAWA et al., 2000). 
Estudos demostraram que a morte celular apoptótica pode sofrer uma transição para a necrótica durante uma situação de estresse oxidativo através de mecanismos como o desencadeamento pela inativação de caspases devido à oxidação do grupo tiol de seus sítios ativos por agentes oxidantes, sendo a Doxorrubicina um agente promotor do aumento de espécies reativas de oxigênio e, consequentemente, corroborando com essa cadeia de eventos. Além da redução nos níveis de ATP, devido à diminuição de função mitocondrial causada pela ação de agentes oxidantes o tratamento in vitro pode ter levado a liberação de citocromo e alteração de permeabilidade de membrana mitocondrial, fazendo com que ocorresse esse mecanismo de transição de via apoptótica para necrose celular (; (CADENAS et al., 2000).

Levando em conta esse mecanismo descrito na literatura, podemos constatar que as associações nas dose Doxorrubicina $0,5 \mu \mathrm{M}+$ Ivermectina $1,5 \mathrm{mM}$ e Doxorrubicina $0,5 \mu \mathrm{M}$ + Ivermectina $2,5 \mathrm{mM}$, foram capazes de promover aumento da morte celular por necrose, ou seja, o uso da ivermectina teve um sinergismo com a Doxorrubicina acarretando uma variação de morte de apoptose e necrose das células tratadas.

O comportamento de migração celular, é uma importante característica da metástase do câncer e estudos demonstraram que a inibição deste passo resulta na prevenção de metástases e são alvos de desenvolvimento de agentes anticancerígenos (SIRIPONG et al., 2012). O processo de migração é extremamente complexo, dependendo principalmente de actina, que é uma proteína responsável por formar os microfilamentos de sustentação e motilidade das células (HOSOOKA et al., 2002).

O ensaio de migração celular pelo método de wound healing, auxiliou a caracterizar os efeitos das associações sobre as células de melanoma, as mesmas

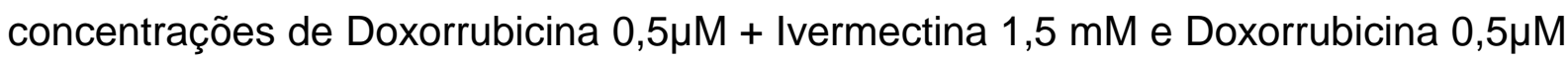
+ Ivermectina 2,5 mM suprimiram significativamente a capacidade de migração das células de melanoma.

As associações obtiveram menor percentual de fechamento, sendo mais eficaz do que a Doxorrubicina isolada, e a medida que o tempo de incubação aumentou para $48 \mathrm{~h}$, a taxa de migração nos três grupos de ivermectina isolados, não interferiu no fechamento da fissura, e não apresentaram diferença estatística significante quando comparada ao controle e ao veículo (DMSO), evidenciando que 
a Ivermectina não foi capaz de promover um citotoxicidade ou interferência no perfil de migração das células de melanoma. Um artigo recente de Li, 2019, visa uma nova associação entre a Doxorrubicina na dose de $0,5 \mu \mathrm{M}$ e a Oridonina (um agente antitumoral derivado de planta), o mesmo obtém como resultado o aumento sinérgico e a eficácia antitumoral contra o câncer de mama, por meio de efeitos próapoptóticos e antiangiogênicos; o artigo demonstra que a Doxorrubicina isolada ou em associação, teve como efeito diminuir o percentual de migração (LI et al., 2019).

Em 1988, Colombo e seu grupo pesquisaram o efeito de diferentes concentrações de Doxorrubicina na bioquímica da motilidade celular e, em particular, na polimerização de actina induzida por potássio o qual foi avaliado in vitro. Os autores deste estudo mostram que quantidades de Doxorrubicina influenciam negativamente a polimerização da actina inibindo o crescimento do filamento. $O$ status de agregação de actina poderia influenciar em muitas manifestações de motilidade celular e migração( COLOMBO, NECCO, VAILATI, 1988).

$O$ efeito que obtivemos sobre a migração celular pode ter influência sobre 0 aumento do percentual de morte das células causado pelo sinergismo entre os dois fármacos, diminuindo a duplicação e o efeito de migração, seja pela perda de aderência causada por citotoxidade ou por vias que envolvem a perda da função de proteínas de adesão como a influência do efeito da Doxorrubicina sobre a actina.

Sendo o efeito inibitório sobre a migração celular muito mais pronunciado nos grupos das associações, podendo indicar o aumento da atividade da Doxorrubicina e sua influência sobre as células tumorais.

Apesar de resultados promissores com o ensaio de migração celular, torna-se necessário utilizar outras técnicas como o ensaio de invasão e outras condições para verificar se o efeito citotóxico tem alguma influência sobre a capacidade de invasão celular.

Sobre a avaliação do ciclo celular as associações de ivermectina e doxorrubicina produziram uma crescente parada em G2 quando comparadas com todos os outros grupos, após as 48 horas de tratamento in vitro.

Em geral sabe-se que a doxorrubicina isolada, apresenta acúmulo das células na fase G2, onde ocorre síntese de componentes para a mitose (divisão celular com manutenção do número de cromossomos), indicando que a droga inibe o ciclo celular e causa morte em células tumorais. Esse arraste da fase G2 impede que a célula entre para fase $(M)$ mitose, ou seja, a iniciação da divisão celular que acarreta 
um menor efeito proliferativo (FURUSAWA et al., 2000).

Este efeito da Doxorrubicina pode ocorrer por se ligar ao DNA, gerando radicais livres, interagindo com membranas celulares e pela influência de seu mecanismo sobre a inibição da topoisomerase II, que desempenha um papel no reparo DNA.

No presente estudo assim como no estudo de Furusawa et. al. (2000) foi demonstrado que a Ivermectina induziu marcantemente um efeito sobre o ciclo celular quando associada a Doxorrubicina, levando a um arraste para fase G2, e esse aumento de arreste se deu de forma proporcional conforme o aumento da dose de Ivermectina.

Todos os resultados obtidos nesse estudo demonstram que essa associação, principalmente nas maiores concentrações ocorreu um sinergismo no tratamento da linhagem melanoma canino (MeLn) in vitro, os quais levaram ao aumento da citotoxicidade, modificação inibitória da migração das células, além de alterar o ciclo celular. Todos esses efeitos quando comparado ao tratamento da Doxorrubicina $0,5 \mu \mathrm{M}$ isolada, se mostraram mais contundentes.

O presente estudo traz sua contribuição no sentido de encorajar novas pesquisas no ramo de reposicionamento farmacológico de agentes que podem ser sinérgicos aos quimioterápicos a fim de potencializar o efeito de antineoplásicos empregados em doses mais baixas. O uso da Ivermectina em doses terapêticas associada a Doxorrubicina pode futuramente ser fruto de estudos em uma abordagem pré-clínica ou clínica, em especial para o tratamento de neoplasias de difícil controle como, por exemplo o melanoma e outros tumores resistentes a quimioterápicos. 


\section{CONCLUSÕES}

- A linhagem celular de melanoma canino metastático extraída de linfonodo, apresentou as características necessárias e adequadas para se duplicar e manter-se em cultivo; os parâmetros de Imunomarcação foram positivos para ambos os marcadores Melan-A e PNL-2, confirmando a histogênese melanocítica da linhagem tumoral.

- $\quad$ A linhagem de células Meln atingiu confluência adequada no ensaio de duplicação e viabilidade para a realização do ensaio de in vitro, e o protocolo pôde ser devidamente estabelecido.

- $\quad$ A associação farmacológica entre a doxorrubicina e a Ivermectina nas doses (Doxorrubicina 0,5 $\mathrm{MM}+$ Ivermectina 1,25 mM e Doxorrubicina $0,5 \mu \mathrm{M}+$ Ivermectina $2,5 \mathrm{mM}$ ) foram capazes de aumentar o percentual de morte celular em relação as drogas isoladas na linhagem de celular esferoide de melanoma canino.

- $\quad \mathrm{O}$ aumento da concentração entre as associações, demonstrou poucas células em apoptose inicial e uma tendência de aumento do percentual de células em apoptose tardia, mas o percentual de morte celular foi mais evidente pela via de necrose celular.

- $\quad$ A associação farmacológica entre a Doxorrubicina e a Ivermectina nas doses (Doxorrubicina 0,5 $\mathrm{MM}+$ Ivermectina 1,25 mM e Doxorrubicina $0,5 \mu \mathrm{M}+$ Ivermectina $2,5 \mathrm{mM}$ ) foi capaz de diminuir a migração das células tumorais, sendo mais eficaz que a Doxorrubicina $0,5 \mu \mathrm{M}$ isolada.

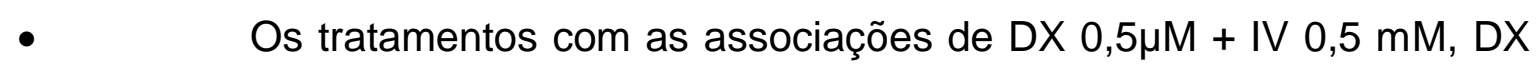
$0,5 \mu \mathrm{M}+\mathrm{IV} 1,5 \mathrm{mM}$ e DX 0,5 $\mu \mathrm{M}+\mathrm{IV} 2,5 \mathrm{mM}$, induziram um arraste do ciclo celular para fase G2, implicando na continuidade do ciclo celular, impedindo que a célula entre para fase (M) mitose, sendo mais evidente do que a Doxorrubicina $0,5 \mu \mathrm{M}$ isolada . 


\section{REFERÊNCIAS}

AMERICAN TYPE CULTURE COLLECTION (ATCC). Thawing, Propagating and Cryopreserving Protocol. SK-MEL-2 Malignant melanoma cells. American Type Collection Culture. EUA, V.1. set. 2013.

ASHLEY, N.; POULTON, J. Mitochondrial DNA is a direct target of anti-cancer anthracycline drugs. Biochemical and Biophysical Research Communications, v. 378, n. 3, p. 450-455, 16 jan. 2009.

BAO, L. et al. Increased expression of P-glycoprotein and doxorubicin chemoresistance of metastatic breast cancer is regulated by miR-298. American Journal of Pathology, v. 180, n. 6, p. 2490-2503, jun. 2012.

BURG, R. W. et al. Avermectins, new family of potent anthelmintic agents: Isolation and chromatographic properties. Antimicrobial Agents and Chemotherapy, v. 15, n. 3, p. 368-371, 1979.

BURGESS, D. J. et al. Topoisomerase levels determine chemotherapy response in vitro and in vivo. Proceedings of the National Academy of Sciences, v. 105, n. 26, p. 9053-9058, 1 jul. 2008.

CADENAS, E. et al. Lars Ernster Commemorative Issue TRIGGERING AND MODULATION OF APOPTOSIS BY OXIDATIVE STRESS. v. 29, n. 00, p. 323-333, 2000.

CARLON, W., MCGAVIN, M.; Patologia Veterinária Especial de Thomson. p.23. Editora Artmed. Porto Alegre, 1998.

CHARTRAIN, M. et al. Melanoma chemotherapy leads to the selection of ABCB5expressing cells. PLoS ONE, v. 7, n. 5, 24 maio 2012. 
COLOMBO, NECCO, VAILATI, M. Dose-dependence of doxorubicin effect on actin assembly in vitro. Experimental and Molecular Pathology, v. 49, n. 3, p. 297-304, 1988.

CRUMP, A. Ivermectin: Enigmatic multifaceted "wonder" drug continues to surprise and exceed expectations. Journal of Antibiotics, v. 70, n. 5, p. 495-505, 2017.

DAHME, E.; WEISS, E., Anatomia Patológica Especial Veterinária. Editora Acribia SA, p. 458, 1989.

DAWSON, R. J. P.; LOCHER, K. P. Structure of a bacterial multidrug ABC transporter. Nature, v. 443, n. 7108, p. 180-185, 14 set. 2006.

DE NARDI, A. B. et al. Prevalência De Neoplasias E Modalidades De Tratamentos Em Cães, Atendidos No Hospital Veterinário Da Universidade Federal Do Paraná. Archives of Veterinary Science, v. 7, n. 2, p. 15-26, 2002.

De Vita. Jr; HELLMAN, S.; Rosenberg, A.S. Cancer - Principles of practice of oncology. 5 ed. Philadelphia: Lippincott-Raven.1997.

DEL GIUDICE, P. Prix Nobel pour l'ivermectine! Annales de Dermatologie et de Venereologie, v. 143, n. 4, p. 249-250, 2016.

DIDIER, A.; LOOR, F. The Abamectin Derivate Ivermectin Is a Potent Glicoproteina P Inhibitor. Anti-Cancer Drugs,v.7, p745-751, jul. 1996.

DOMINGUEZ, G. et al. Ivermectin as an inhibitor of cancer stem-like cells. Molecular Medicine; v.17, p. 3397- 3403, fev. 2018.

DORASAMY, M. S. et al. Synergistic inhibition of melanoma xenografts by Brequinar sodium and Doxorubicin. Biomedicine and Pharmacotherapy, v. 110, p. 29-36, 1 fev. 2019. 
DOU, Q. et al. Ivermectin induces cytostatic autophagy by blocking the PAK1/Akt axis in breast cancer. Cancer Research, v.76, p.4457-4469, jun. 2016

DRAGANOV D, et al. Modulation of P2X4/P2X7/Pannexin-1 sensitivity to extracellular ATP via Ivermectin induces a non-apoptotic and inflammatory form of cancer cell death. Scientific Reports, v10, n.5, p 1-17, nov. 2015;

DRINYAEV, V. A. et al. Antitumor effect of avermectins. European Journal of Pharmacology, v. 501, n. 1-3, p. 19-23, 2004.

EGERTON, J. R. et al. Avermectins, new family of potent anthelmintic agents: Efficacy of the B1(a) component. Antimicrobial Agents and Chemotherapy, v. 15, n. 3, p. 372-378, 1979.

ECKHOLM, E. Conquering an ancient scourge; river blindness. New York Times Magazine, p.20-27, Jan, 1989.

FINOTELLO, R. et al. Immunohistochemical expression of MDR1-Pgp 170 in canine cutaneous and oral melanomas: pattern of expression and association with tumour location and phenotype. Veterinary and Comparative Oncology, v. 15, n. 4, p. 1393-1402, dez. 2017.

FURUSAWA, S. et al. Potentiation of Doxorubicin-Induced Apoptosis of Resistant Mouse Leukaemia Cells by Ivermectin. Pharmacy and Pharmacology Communications, v. 6, n. 3, p. 129-134, 2000.

GEARY, T. G. Ivermectin 20 years on: Maturation of a wonder drug. Trends in Parasitology, v. 21, n. 11, p. 530-532, 2005.

GOLAN, David E. Princípios de farmacologia: a base fisiopatológica da farmacoterapia. 2. ed. Rio de Janeiro: Guanabara Koogan, 2009.

GOLDSCHMIDT, M. H.; GOLDSCHMIDT, K. H. Epithelial and Melanocytic Tumors of the Skin. Tumors in Domestic Animals, p. 88-141, 2016. 
GREENE, R. F. et al. Plasma pharmacokinetics of adriamycin and adriamycinol: Implications for the design of in vitro experiments and treatment protocols. Cancer Research, v. 43, n. 7, p. 3417-3421, 1983.

GUPTA, S. C. et al. Cancer drug discovery by repurposing: Teaching new tricks to old dogs. Trends in Pharmacological Sciences, v. 34, n. 9, p. 508-517, 2013.

HANDE, K. R. Topoisomerase II inhibitors. Update on Cancer Therapeutics, v. 3, n. 1, p. 13-26, 2008.

HANAHAN, D.; WEINBERG, R.A. The Hallmarks of Cancer. Cell, v. 100, p. 57-70. 2000.

HASHIMOTO, $\mathrm{H}$. et al. Ivermectin inactivates the kinase PAK1 and blocks the PAK1dependent growth of human ovarian cancer and NF2 tumor cell lines. Drug Discovery, v.3, p. 243-6, nov. 2009.

HAY, M. et al. Nature biotech mabs phase success. v. 32, n. 1, 2014.

HAYES, J. D.; WOLF, C. R. Molecular mechanisms of drug resistance John. Biochemical Journal, v. 272, p. 1-3, 1990.

HIGGINS, C. F. Flip-flop: The transmembrane translocation of lipids. Cell, v. 79, n. 3, p. 393-395, 1994.

HILL, B. T. Drug resistance: An overview of the current state of the art. International Journal of Oncology, v. 9, n. 2, p. 197-203, 1996.

HORIKAWA, $H$. et al. Genome sequence of an industrial microorganism Streptomyces avermitilis: Deducing the ability of producing secondary metabolites. Proceedings of the National Academy of Sciences, v. 98, n. 21, p. 12215-12220, 2002. 
HOSOOKA, T. et al. Inhibition of the Motility and Growth of B16F10 Mouse Melanoma Cells by Dominant Negative Mutants of Dok-1. Molecular and Cellular Biology, v. 21, n. 16, p. 5437-5446, 2002.

HULKOWER, K. I.; HERBER, R. L. Cell migration and invasion assays as tools for drug discovery. Pharmaceutics, v. 3, n. 1, p. 107-124, 2011.

IKEDA, $\mathrm{H}$. et al. Complete genome sequence and comparative analysis of the industrial microorganism Streptomyces avermitilis. Nature Biotechnology, v. 21, n. 5, p. 526-531, 2003.

JUAREZ, M.; SCHCOLNIK-CABRERA, A.; DUEÑAS-GONZALEZ, A. The multitargeted drug ivermectin: from an antiparasitic agent to a repositioned cancer drug. American journal of cancer research, v. 8, n. 2, p. 317-331, 2018.

JULIANO, R. L.; LING, V. A surface glycoprotein modulating drug permeability in Chinese hamster ovary cell mutants. BBA - Biomembranes, v. 455, n. 1, p. 152$162,1976$.

KELLER-MELCHIOR, R.; SCHMIDT, R.; PIEPKORN, M. Expression of the tumor suppressor gene product p16(INK4) in benign and malignant melanocytic lesions. Journal of Investigative Dermatology, v. 110, n. 6, p. 932-938, 1998.

KELLNER, U.; PARWARESCH, R. Human DNA-Topoisomerases - Diagnostic and. p. 424-430, 2000.

KESHET, G. I. et al. MDR1 expression identifies human melanoma stem cells. Biochemical and Biophysical Research Communications, v. 368, n. 4, p. 930936, 18 abr. 2008.

KUFE, D. W.; POLLOCK, R. E.; WEICHSELBAUM, R. R.; GANSLER, T. S.; BAST, R. C. J. Holland-Frei Cancer Medicine. 6 ed. BC Decker Inc., 2003. 
LAI, S.-L. et al. MDR1 gene expression in lung cancer. Journal of the National Cancer Institute, v. 81, n. 15, p. 1144-1150, 1989.

LANGEDIJK, J. et al. Drug repositioning and repurposing: terminology and definitions in literature. Drug Discovery Today, v. 20, n. 8, p. 1027-1034, 2015.

LEVINE, B.; KROEMER, G. Autophagy in the Pathogenesis of Disease. Cell, v. 132, n. 1, p. 27-42, 2008.

LI, J. et al. Oridonin synergistically enhances the anti-tumor efficacy of doxorubicin against aggressive breast cancer via pro-apoptotic and anti-angiogenic effects. Pharmacological Research, v. 146, n. February, p. 104313, 2019.

LITMAN, T. et al. From MDR to MXR: New understanding of multidrug resistance systems, their properties and clinical significanceCellular and Molecular Life SciencesBirkhauser Verlag Basel, , 2001.

LIU, Y. et al. Anthelmintic drug ivermectin inhibits angiogenesis, growth and survival of glioblastoma through inducing mitochondrial dysfunction and oxidative stress. Biochemical and Biophysical Research Communications, v. 480, n. 3, p. 415421, 2016.

LEFRANC, F.; MATHIEU, V.; KISS, R. Galectin-1-mediated biochemical controls of melanoma and glioma aggressive behavior. World Journal of Biological Chemistry, v. 2, n. 9, p. 193-201, 2011.

LOO, T. W.; CLARKE, D. M. P-glycoprotein ATPase activity requires lipids to activate a switch at the first transmission interface. Biochemical and Biophysical Research Communications, v. 472, n. 2, p. 379-383, 1 abr. 2016.

LOWN, J.W. Discovery and Development of Anthracycline Antitumour Antibiotics. Chemical. Society Reviews, v.22, p.165-176,1993. 
MALUMBRES, M.; BARBACID, M. Cell cycle, CDKs and cancer: A changing paradigm. Nature Reviews Cancer, v. 9, n. 3, p. 153-166, 2009.

MELOTTI, A. et al. The river blindness drug Ivermectin and related macrocyclic lactones inhibit WNT-TCF pathway responses in human cancer. EMBO Molecular Medicine, v.6, n.10, p.1263-1278, out. 2014

MEYERSON, M. Role of Telomerase in Normal and Cancer Cells. Miscellaneous Article, v. 18, n. 13, p. 2626-2634, 2000.

MINOTTI, G. Anthracyclines: Molecular Advances and Pharmacologic Developments in Antitumor Activity and Cardiotoxicity. Pharmacological Reviews, v. 56, n. 2, p. 185-229, jun. 2004.

MODIANO, J. F.; RITT, M. G.; WOJCIESZYN, J. The molecular basis of canine melanoma: pathogenesis and trends in diagnosis and therapy. Journal of veterinary internal medicine / American College of Veterinary Internal Medicine, v. 13, n. 3, p. 163-174, 1999.

NANAYAKKARA, A. K. et al. Targeted inhibitors of P-glycoprotein increase chemotherapeutic-induced mortality of multidrug resistant tumor cells. Scientific Reports, v. 8, n. 1, dez. 2018.

NISHIYA, A. et al. Comparative Aspects of Canine Melanoma. Veterinary Sciences, v. 3, n. 1, p. 7, 2016.

ÕMURA, S. Ivermectin: 25 years and still going strong. International Journal of Antimicrobial Agents, v. 31, n. 2, p. 91-98, 2008.

ÕMURA, S. et al. The life and times of ivermectin: a success story. Nature Reviews Microbiology, v.2, p. 984-989, 2004. 
ONG, S. M. et al. Anti-neoplastic effects of topoisomerase inhibitors in canine mammary carcinoma, melanoma, and osteosarcoma cell lines. Japanese Journal of Veterinary Research, v. 65, n. 1, p. 17-28, 2017.

POULIOT, J. F. et al. Reversal of P-glycoprotein-associated multidrug resistance by ivermectin. Biochemical Pharmacology, v. 53, n. 1, p. 17-25, jan. 1997.

Pulliam, J.D. et al. Investigating ivermectin toxicity in Collies. Jounal Veterinary Therapeutic, v.8, p.33 - 40, 1985.

RAMOS-VARA, J. A.; MILLER, M. A. Immunohistochemical identification of canine melanocytic neoplasms with antibodies to melanocytic antigen PNL2 and tyrosinase: Comparison with melan A. Veterinary Pathology, v. 48, n. 2, p. 443-450, 2011.

SMITH, S. H.; GOLDSCHMIDT, M. H.. A Comparative Review of Melanocytic Neoplasms. Veterinary Pathology, v. 39, n. 6, p. 651-678, 2002.

SAFA, A. R. Photoaffinity analogs for multidrug resistance-related transporters and their use in identifying chemosensitizers. Drug Resistance Updates, v. 2, n. 6, p. 371-381, 1999.

SAMPAIO, F. C.; BERTONI, V.D.; SAMPAIO, C.; PIMENTA. A.; BRANDÃO, M.A. Agentes antineoplásicos. In: Penildon, S. (org.) Farmacologia. 7. ed. Rio de Janeiro: Guanabara Koogan, p. 1055-1070, 2006.

SCHINKEL, A. H. et al. Disruption of the mouse mdr1a P-glycoprotein gene leads to a deficiency in the blood-brain barrier and to increased sensitivity to drugs. Cell, v. 77, n. 4, p. 491-502, 20 maio 1994.

SETH, C. et al. Long-Lasting WNT-TCF response blocking and epigenetic modifying activities of withanolide $\mathrm{f}$ in human cancer cells. PLoS One 2016; 
SHAMEER, K.; READHEAD, B.; DUDLEY, J. T. Computational and experimental advances in drug repositioning for accelerated therapeutic stratification. Current topics in medicinal chemistry, v. 15, n. 1, p. 5-20, 2015.

SHARMEEN, S. et al. The antiparasitic agent ivermectin induces chloride-dependent membrane hyperpolarization and cell death in leukemia cells. Blood, v.116, n.18.p. 3593-3603, nov. 2010.

SIRIPONG, P. et al. Anti-metastatic effects on B16F10 melanoma cells of extracts and two prenylated xanthones isolated from Maclura amboinensis $\mathrm{BI}$ roots. Asian Pacific journal of cancer prevention : APJCP, v. 13, n. 7, p. 3519-28, 2012.

STARKEY, M. P. et al. Dogs really are man's best friend - Canine genomics has applications in veterinary and human medicine! Briefings in Functional Genomics and Proteomics, v. 4, n. 2, p. 112-128, 2005.

STEPHEN.J. BICHARD; ROBERT. G. SHERDIG: Clínica de Pequenos Animais (Manual Saunders). São Paulo: Ed. Roca. A 1998, p. 1075.

TAKANASHI, S.; BACHUR NR. Adriamycin metabolim in man.Evidence from urinary metabolites. Drug Metabolism, v.4, n.1, p 79-87, 1976.

VAN DEN OORD, J. et al. Reduced tumorigenicity and pathogenicity of cervical carcinoma SiHa cells selected for resistance to cidofovir. Molecular Cancer, v. 12, n. 1, p. 158, 2013.

VILELA, M. J. et al. Determinação de padrões de crescimento de células em cultura. Jornal Brasileiro de Patologia e Medicina Laboratorial, v. 39, n. 1, p. 67-72, 2005.

WINNER E. et al. Malignant tumors of the breast. In: DeVita VT Jr, Hellman S., Rosenberg SA, eds. Cancer: Principles and Practice of Oncology. 6th edition. Philadelphia, Pa: Lippincott Williams \& Wilkins 2001;1651-1717. 
WÜRTH, R. et al. Drug-repositioning opportunities for cancer therapy: Novel molecular targets for known compounds. Drug Discovery Today, v. 21, n. 1, p. 190199, 2016.

YIN J, et al. DEAD-Box RNA helicase DDX23 modulates glioma malignancy via elevating miR-21 biogenesis. Brain, v.70, n.138, p. 2553-2570, jul. 2015.

YUE, P. Y. K. et al. A Simplified Method for Quantifying Cell Migration/Wound Healing in 96-Well Plates. Journal of Biomolecular Screening, v. 15, n. 4, p. 427433, 2010.

ZAMORA, J. M.; PEARCE, H. L.; BECK, W. T. Physical-chemical properties shared by compounds that modulate multidrug resistance in human leukemic cells. Molecular pharmacology, v. 33, n. 4, p. 454-62, 1988.

ZHU, M.; LI, Y.; ZHOU, Z. Antibiotic ivermectin preferentially targets renal cancer through inducing mitochondrial dysfunction and oxidative damage. Biochemical and Biophysical Research Communications, v. 492, n. 3, p. 373-378, 2017. 